\title{
Terrestrial engagements by terminal Lapita maritime specialists on the southern Papuan coast
}

\section{Ian J. McNiven}

School of Geography and Environmental Science, Monash University, Clayton, Victoria ian.mcniven@monash.edu

\section{Bruno David}

Monash University, Clayton, Victoria

\section{Ken Aplin}

National Museum of Natural History, Smithsonian Institution, Washington D.C., United States of America

\section{Jerome Mialanes}

Monash University, Clayton, Victoria

\section{Brit Asmussen}

Queensland Museum, South Brisbane, Queensland

\section{Sean Ulm}

James Cook University, Cairns, Queensland

\section{Patrick Faulkner}

University of Queensland, Brisbane, Queensland

\section{Cassandra Rowe}

Monash University, Clayton, Victoria

\section{Thomas Richards}

Monash University, Clayton, Victoria 


\section{Introduction}

In 1974, Peter Kershaw published a paper in Nature outlining a remarkable pollen core sequence from Lynch's Crater in tropical northeast Queensland (Kershaw 1974). From an archaeological perspective, the most interesting dimension to this work was the novel and provocative suggestion that the transition from rainforest to sclerophyll forest beginning around 38,000 BP may have been related to anthropogenic burning of the landscape since Aboriginal colonisation of the continent (Kershaw 1974:222). In a sense, Kershaw was giving empirical veracity to Rhys Jones's (1969) paradigmatic notion of 'fire-stick farming' and the proposition that 'the arrival of Aboriginal man [to Australia] increased the fire frequency by an enormous amount'. In 1981, Kershaw and colleagues gave further support to the anthropogenic burning interpretation by showing increases in charcoal counts within the Lynch's Crater core coincident with the rainforest-sclerophyll forest transition (Singh et al. 1981). While initially archaeologists were wary of this new and alternative approach to the human past in Australia, by 1993 Kershaw could rightly claim that 'information from some pollen records has been important to the debate on the time of arrival of Aboriginal people' (Kershaw 1993:14).

A key concern of archaeologists over the use of pollen and charcoal records to date human colonisation was the controversial claim that charcoal in some cores pointed to an Aboriginal presence well over 100,000 years ago and well before the earliest archaeological evidence of less than 50,000 years ago (Singh et al. 1981; White and O'Connell 1982:42; Kershaw 1993). Yet few disagreed with the general thrust of Singh et al.'s (1981:45) proposition that 'the impact of the increase in the frequency of fires through the early activities of Man may have been marked, so that evidence from the vegetation history of an area might be used to supplement, or foreshadow, the archaeological record'. More recently, Hiscock (2008:37) has suggested that fire records at sites such as Lynch's Crater may underestimate human presence, as 'intensified fire frequencies might signal a time when humans began regularly using fire to burn their ecosystem, which could be long after the colonisation of Australia'. Despite these useful caveats, the re-dating of anthropogenic firing at Lynch's Crater to 45,000 years ago by Kershaw and colleagues (Turney et al. 2001) now comes close to current archaeological evidence for the antiquity of the human colonisation of Australia (O'Connell and Allen 2004; see also Mooney et al. 2011).

To the immediate north of Australia in New Guinea, palaeoenvironmental approaches to human colonisation and use of landscapes have similarly complemented archaeological approaches to the human past (Hope and Haberle 2005). Here, one question that has long intrigued archaeologists and ecologists alike is the history and formation of grasslands across various parts of the highlands and the role of human vegetation clearance and landscape firing in this process, particularly over the past 4000 years (e.g. Hope 1976, 1983, 2009; Haberle 1998; Haberle et al. 2001; Swadling and Hope 1992). Indeed, such is the scale and significance of these anthropogenic transformations that Hope et al. (1983:41) suggest that 'Man-made landscapes occur over about 200,000 km² [25\%] of the $800,000 \mathrm{~km}^{2}$ of New Guinea'.

Intense research into the impacts of human colonisation and long-term occupation of the Papua New Guinea highlands has not been matched across the surrounding coastal lowlands. In terms of Pleistocene occupation, this paucity of research has led to a situation where 'there are no coastal sites from mainland New Guinea that can provide data with which to assess human impacts on the coastal resources for this crucial early period of time' (Summerhayes et al. 2009:730). A similar situation exists for insular eastern Papua New Guinea, where evidence for 'an environmental impact signature for these early peoples' during the Pleistocene is generally lacking (Summerhayes et al. 2009:731). Yet the lowlands (or at least islands) were the setting for the second major colonisation process across Melanesia - Austronesian expansions, particularly 
those associated with Lapita peoples of the past ca. 3500 years. As Enright and Gosden (1992) and Summerhayes et al. (2009) point out, here evidence for human environmental impacts becomes much more apparent in terms of:

- introduction of new animals (e.g. pigs, dogs, rats);

- introduction of horticultural plants (e.g. bananas);

- extinctions (e.g. birds);

- firing of vegetation (associated with agriculture and hunting);

- accelerated erosion of hillsides; and

- lowland sedimentation and coastal progradation.

Insights into Austronesian environmental impacts on the New Guinea mainland are negligible, as until now no conclusive evidence for Lapita settlement of mainland New Guinea had been found (e.g. Lilley 2008:79) and the period of concern reveals 'very little correlation with [anthropogenic] environmental change' (Hope and Haberle 2005:548). The recent excavation of Lapita and post-Lapita sites dating between 2900 and 2000 years ago at Caution Bay immediately northwest of Port Moresby, southern Papua New Guinea, negates the first conclusion of a purported absence of Lapita, and provides scope to challenge the second (McNiven et al.2011). For 40 years, the accepted view has been that Austronesian colonisation of the southern Papuan coast took place around 2000 years ago by maritime peoples possessing a pottery tradition similar to but post-dating Lapita (David et al. in press). Ethnographically, the descendants of these peoples in the Port Moresby region practised a mixed economy of marine fishing and shellfishing, along with wallaby hunting across grasslands and savannah vegetation maintained by firing. While the antiquity of this process of anthropogenic landscape modification is unknown, it is considered to be no more than 2000 years ago. Here, we extend the known antiquity of mixed economic practices and possible anthropogenic landscape modification in the Port Moresby region using recent excavation results from Caution Bay, focusing on Edubu 1 site, dating from <2350 to $2650 \mathrm{cal} \mathrm{BP}$. Our key aim is to establish a historical framework for pre-2000 cal BP human landscape engagements and transformations along the southern coast of mainland Papua New Guinea.

\section{Edubu 1}

Edubu 1 (aka AH15) is located $1 \mathrm{~km}$ inland from the southern end of Caution Bay and $20 \mathrm{~km}$ northwest of Port Moresby (Figure 1). The site name refers to the local place name for a nearby creek. The site falls within the Fairfax Land System, with characteristic gently undulating terrain, brown clay soils and savannah and grassland dominated by Themeda australis grass and Eucalyptus trees (Mabbutt et al. 1965). The site is $19 \mathrm{~m}$ above sea level within the Vaihua River drainage catchment and is positioned on flat to gently sloping ground elevated above the southern margins of Moiapu creek, which supports Pandanus trees. It is on the ecotone of grasslands (that extend inland from the coast) and the start of open woodlands and eucalypt savannah (Paijmans 1975). Narrow zones of riparian or gallery forest vegetation can be found along some waterways and along the frontal dune flanking the nearby shoreline. Extensive mangrove forests up to $600 \mathrm{~m}$ wide front Caution Bay opposite the site. The Owen Stanley Range provides a visually impressive backdrop to the area and commences its steep rise around $40 \mathrm{~km}$ inland. As part of the broader Port Moresby region, Caution Bay experiences a tropical monsoonal climate with a characteristic wet season (December to April), which accounts for $80 \%$ of precipitation, and a dry season (April to November) (McAlpine et al. 1983). Annual rainfall averages $1000 \mathrm{~mm}$ on the coast and increases nearly four-fold, moving inland over a 
distance of $50 \mathrm{~km}$ (Mabbutt et al. 1965:89).

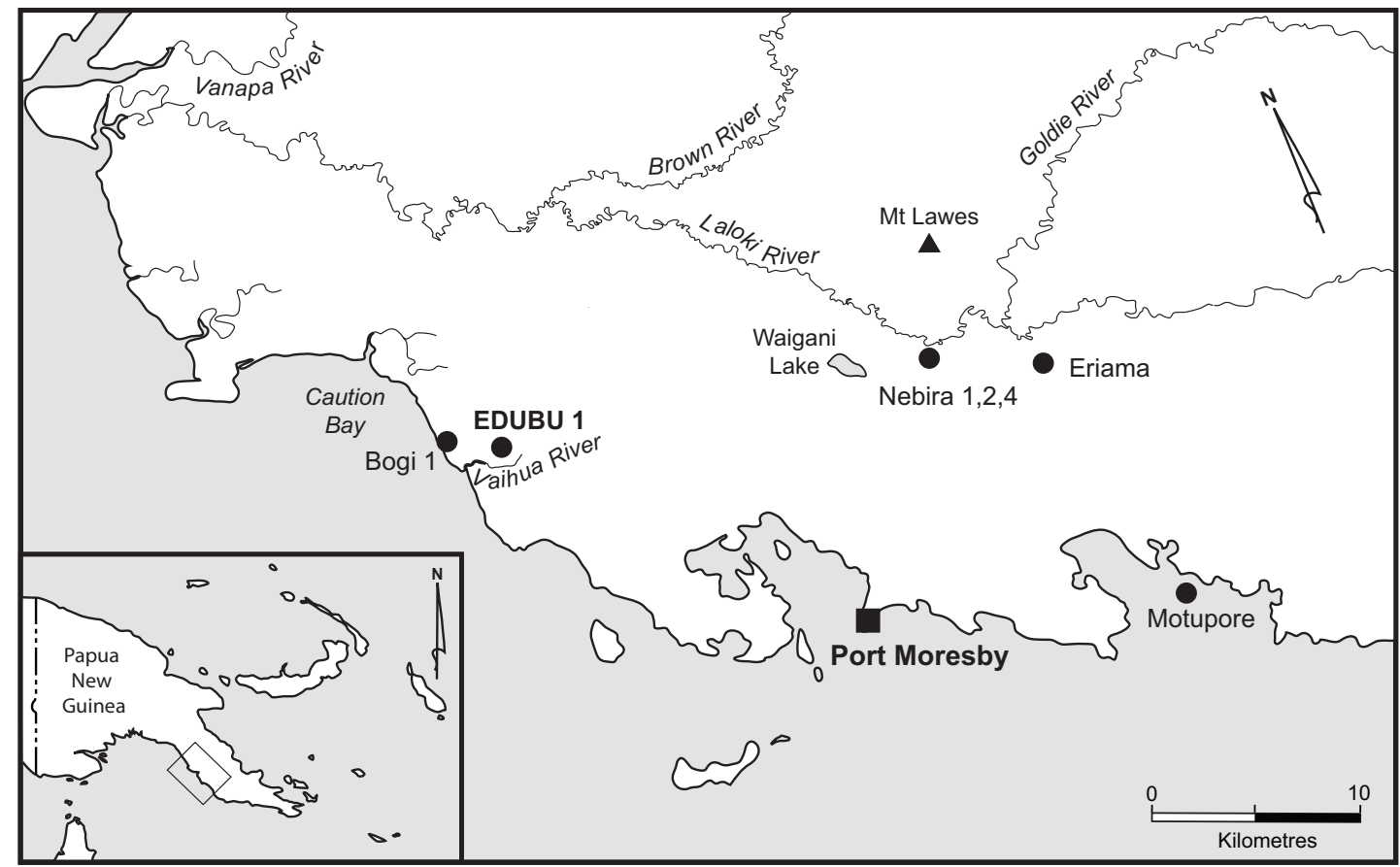

Figure 1. Study area.

\section{Site description}

Edubu 1 is located on a flat area that drops away on the northwest side down to an ephemeral waterway known locally as Moiapu creek (Figure 2). The site is covered in grass, with scattered and isolated low shrubs. Sediments are silty clays. The adjacent waterway is also covered in grass but includes scattered pandanus trees. The archaeological site extends along the edge of the flat land and down the slope towards the waterway. The highest concentration of cultural material is located between the top of the slope and back across the flat for some $10 \mathrm{~m}$. The length of the site is at least $30 \mathrm{~m}$. Cultural material extends down the slope towards the waterway for a distance of $10 \mathrm{~m}$. Most if not all of the slope cultural materials derive from in-situ cultural deposits up on the flat area. Cultural materials across the site surface are mainly marine shells, flaked stone artefacts, fire-cracked rocks and pottery sherds. A low termite mound was located in the middle of the site up on the flat area. Squares $\mathrm{A}$ to $\mathrm{C}$ were located across the main concentration of surface cultural materials on the flat area. However, Square $\mathrm{C}$ was located on the edge of the flat area and presumably the edge of the main settlement area.

\section{Excavation and stratigraphy}

Three $1 \mathrm{~m} \mathrm{x} 1 \mathrm{~m}$ pits (Squares A, B and C) were excavated across Edubu 1. The three squares were aligned in an approximate southwest-northeast direction, with Square $\mathrm{A}$ in the southwest and Square C in the northeast. Centrally located Square B was located $7 \mathrm{~m}$ from Square A and $6 \mathrm{~m}$ from Square C, the distance between Squares A and C being $13 \mathrm{~m}$. Similar but not identical cultural deposit was encountered in all squares. For the purposes of this chapter, analyses focus on Square A, which revealed less post-depositional disturbance and greater stratigraphic integrity than Squares B and C. Square A was dug to a maximum depth of $90 \mathrm{~cm}$ (southeast corner) in 40 Excavation Units (XUs), with a mean thickness of $2.2 \mathrm{~cm}$ (Figure 3). The weight and volume of each XU was measured to the nearest $0.5 \mathrm{~kg}$ and 0.5 litres respectively. Elevations were taken at the start and end of each XU and bulk sediment samples were taken for each XU. All excavated sediments were wet sieved through $2.1 \mathrm{~mm}$ mesh. 


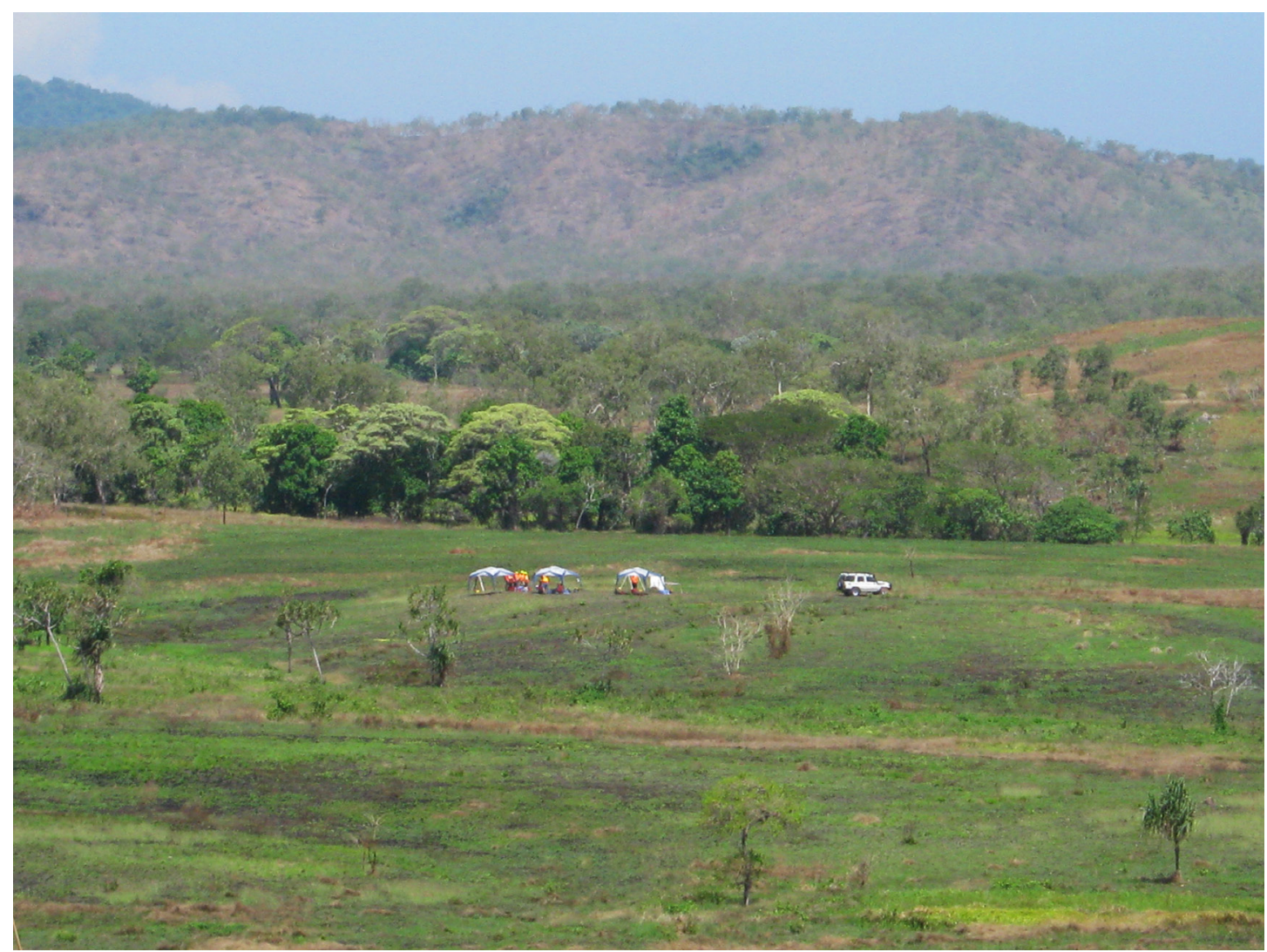

Figure 2. Edubu 1 during excavation, with Moiapu creek in the foreground (looking southeast), 28 September 2009. Squares A to C located right to left are positioned under each shade tent. Photo: Ian J. McNiven.

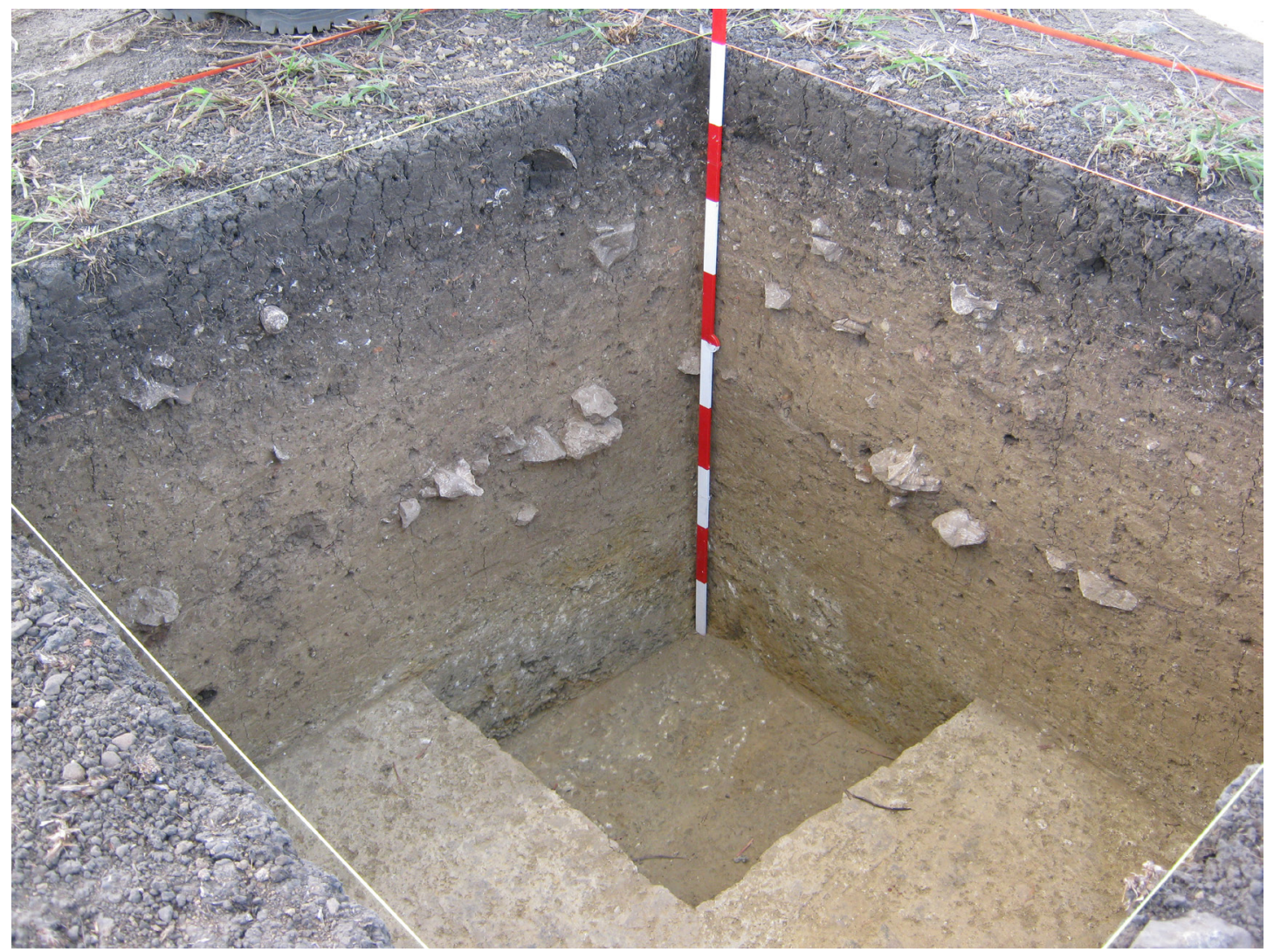

Figure 3. Edubu 1 Square $A$, east and south sections, at end of excavation (scale in $10 \mathrm{~cm}$ units). Photo: Ian J. McNiven. 
Diagnostic and fragile artefacts (e.g. obsidian, decorated ceramic sherds, adzes) and charcoal fragments for AMS dating were plotted in 3D and bagged separately.

The deposit was divided into four major Stratigraphic Units (SUs) (Figure 4). SUs 1 to 3 account for the upper three-quarters of the deposit and are the main layers bearing cultural materials (e.g. shells, bones, stone artefacts and pottery). SU1 is consolidated very dark brown to black silty clay and takes in the upper $13 \mathrm{~cm}$ of the deposit. SU2 is consolidated dark-brown silty clay that varies in depth from $16 \mathrm{~cm}$ to $29 \mathrm{~cm}$ below the surface. SU3 is consolidated brown clay with a maximum depth of $68 \mathrm{~cm}$. SU3a was isolated due to infiltration of SU2 sediments. SU3b is slightly more consolidated and mottled compared with other SU3 sediments. SU3c sediments contain few cultural materials. SUs $3 \mathrm{~d}$ to $3 \mathrm{f}$ represent burrows. SU4 features consolidated clays that take in the lower $27 \mathrm{~cm}$ of deposit. SU4a is consolidated brown clay, with mottling and some cultural materials from infiltration of SU3c sediments. SUs $4 b$ to $4 c$ are culturally sterile and mottled sediments, with layer orientation tilting downwards and very different to that seen for SUs 1 to 3. Sediments vary from mottled orange and brown clays (SU4b), to mottled white, grey and brown clays with limestone inclusions (SU4c), and mottled grey and dark-brown clays (SU4d).

\section{Cultural materials}

Square A contains a diverse range of cultural materials. They include: marine shell $(24,090.1 \mathrm{~g})$, sea-urchin exoskeleton (1757.5 g), crustacean exoskeleton (49.8 g), bone (283.3 $\mathrm{g})$, egg shell $(<0.1 \mathrm{~g})$, ceramic sherds $(6552.2 \mathrm{~g})$, stone artefacts $(1776.7 \mathrm{~g})$ and charcoal $(0.9 \mathrm{~g})$. Vertical changes in the distribution of these cultural materials reveal three major concentrations of activity - an upper concentration between XU1 and XU16 $(0 \mathrm{~cm}$ to $38 \mathrm{~cm}$ below the surface) and a middle concentration between XU16 and XU23 (38 cm to $52 \mathrm{~cm}$ below the surface), which merge at their boundary, and a more isolated lower concentration between XU27 and XU32 (60 $\mathrm{cm}$ to $73 \mathrm{~cm}$ below the surface) (Figure 5).

\section{Radiocarbon dating and chronology}

Eight AMS radiocarbon dates are available for Edubu 1 (Table 1). All dates were obtained on single fragments of wood charcoal and determined by the University of Waikato Radiocarbon Dating Laboratory in New Zealand. Radiocarbon dates were calibrated into calendar years using the online calibration program Calib 6.0 (Stuiver and Reimer 1993) and the IntCal09 dataset (Reimer et al.2009). Due to a paucity of charcoal in the site, a more comprehensive and additional series of AMS dates is planned using marine shell, applying species-specific Delta- $\mathrm{R}$ marine reservoir correction values for the Caution Bay area as determined by a comprehensive program of paired shell-charcoal dates from the area.

The available charcoal dates range from $2339 \pm 30 \mathrm{BP}$ (ca. $2350 \mathrm{cal} \mathrm{BP}$ ) to $2546 \pm 30 \mathrm{BP}$ (ca. 2650 cal BP). The two dates for Square A come from near the base of the upper (ca. 2350 cal BP) and middle (ca. $2500 \mathrm{cal} \mathrm{BP}$ ) concentrations of cultural materials. Insight into the age of the lower concentration of cultural materials is provided by the six AMS dates in Squares B and C. The lowest and oldest dates in Square B (XU29a) and Square C (XU22) are $2520 \pm$ $30 \mathrm{BP}$ (ca. $2600 \mathrm{cal} \mathrm{BP}$ ) and $2546 \pm 30 \mathrm{BP}$ (ca. $2650 \mathrm{cal} \mathrm{BP}$ ) respectively. These dates suggest strongly that the lowest cultural materials in Square A date to around 2600-2650 cal BP, or more broadly to within the period $2500-2750 \mathrm{cal} \mathrm{BP}$ at 2 sigma probability.

\section{Subsistence (marine)}

Shellfish. Marine mollusc shells were recovered from throughout the $90 \mathrm{~cm}$-deep Square A sequence, with nearly all (99.9\% by weight) recovered from XUs 1 to 32, taking in the three concentrations of cultural materials down to a depth of $73 \mathrm{~cm}$. The assemblage comprised 

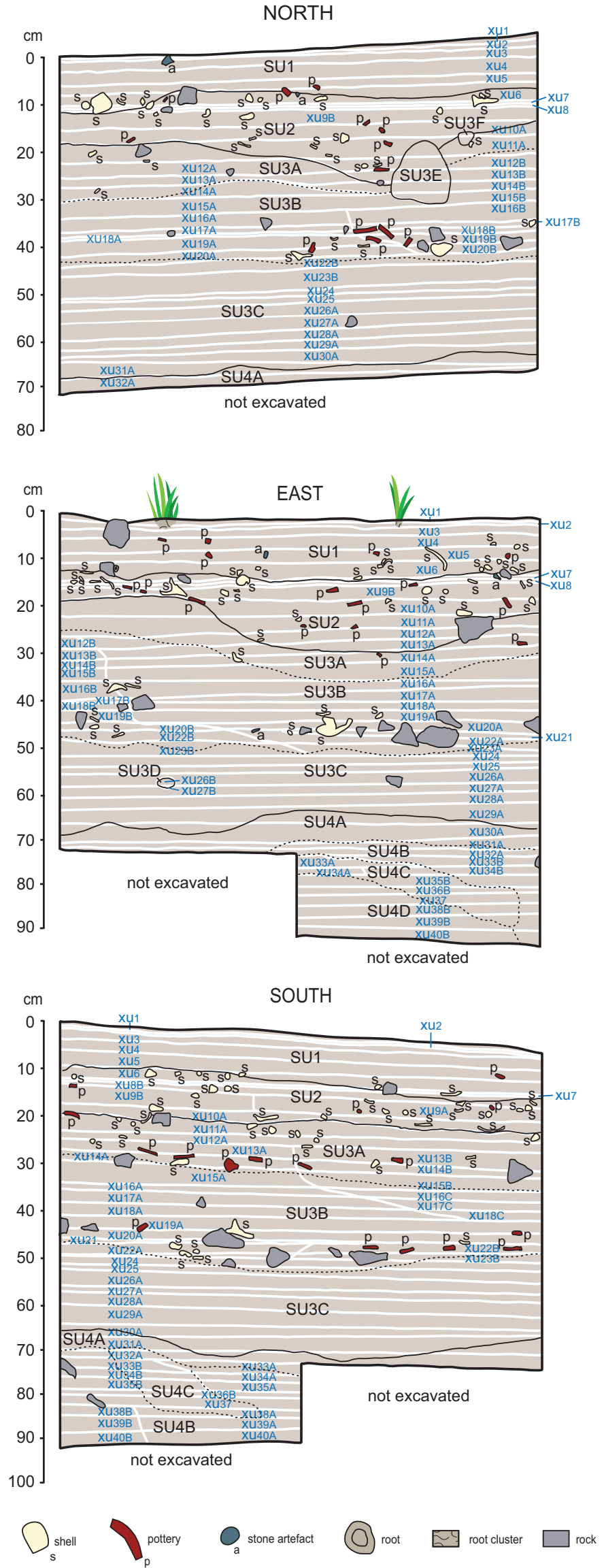

Figure 4. Stratigraphy, Square A, Edubu 1. 

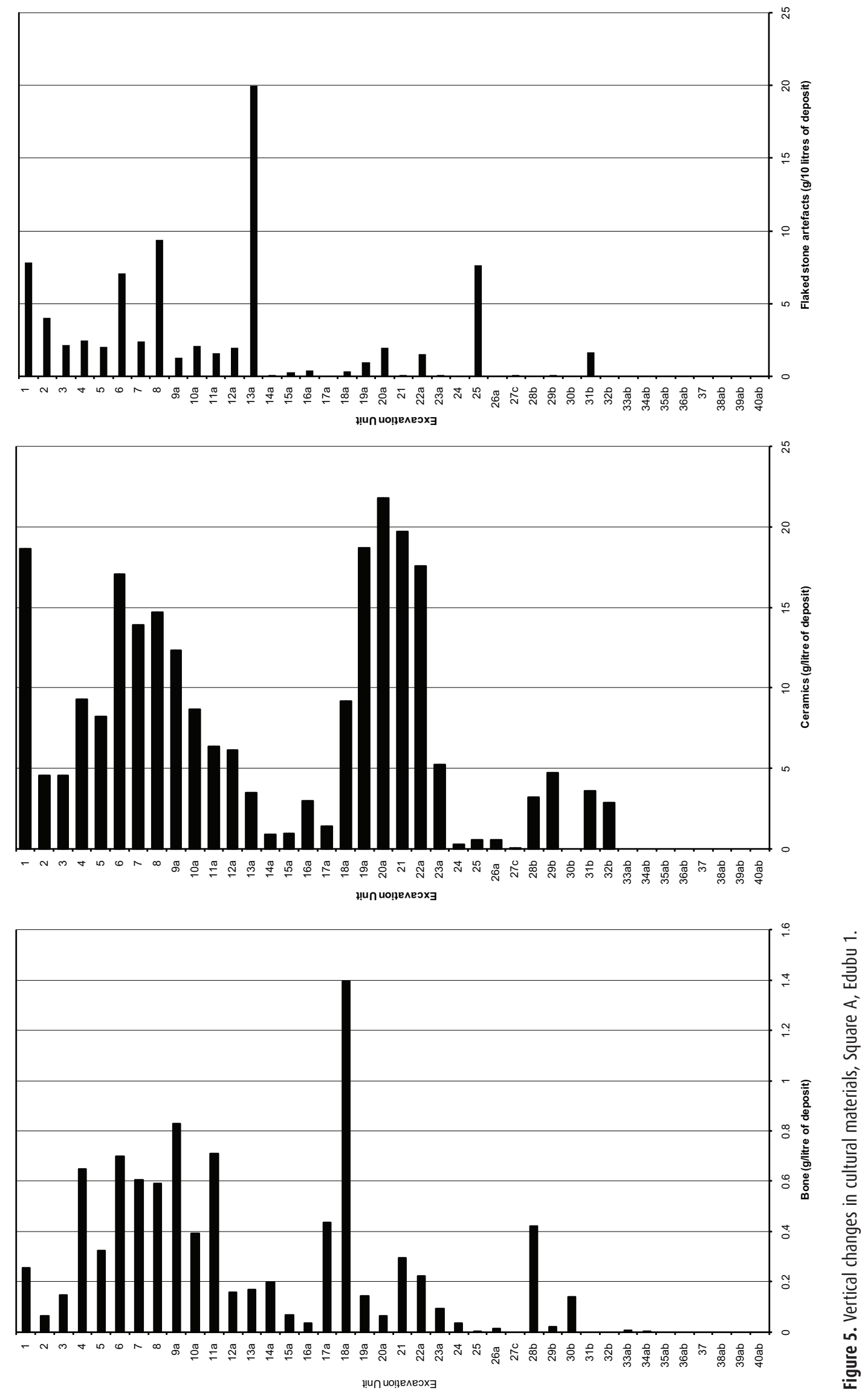

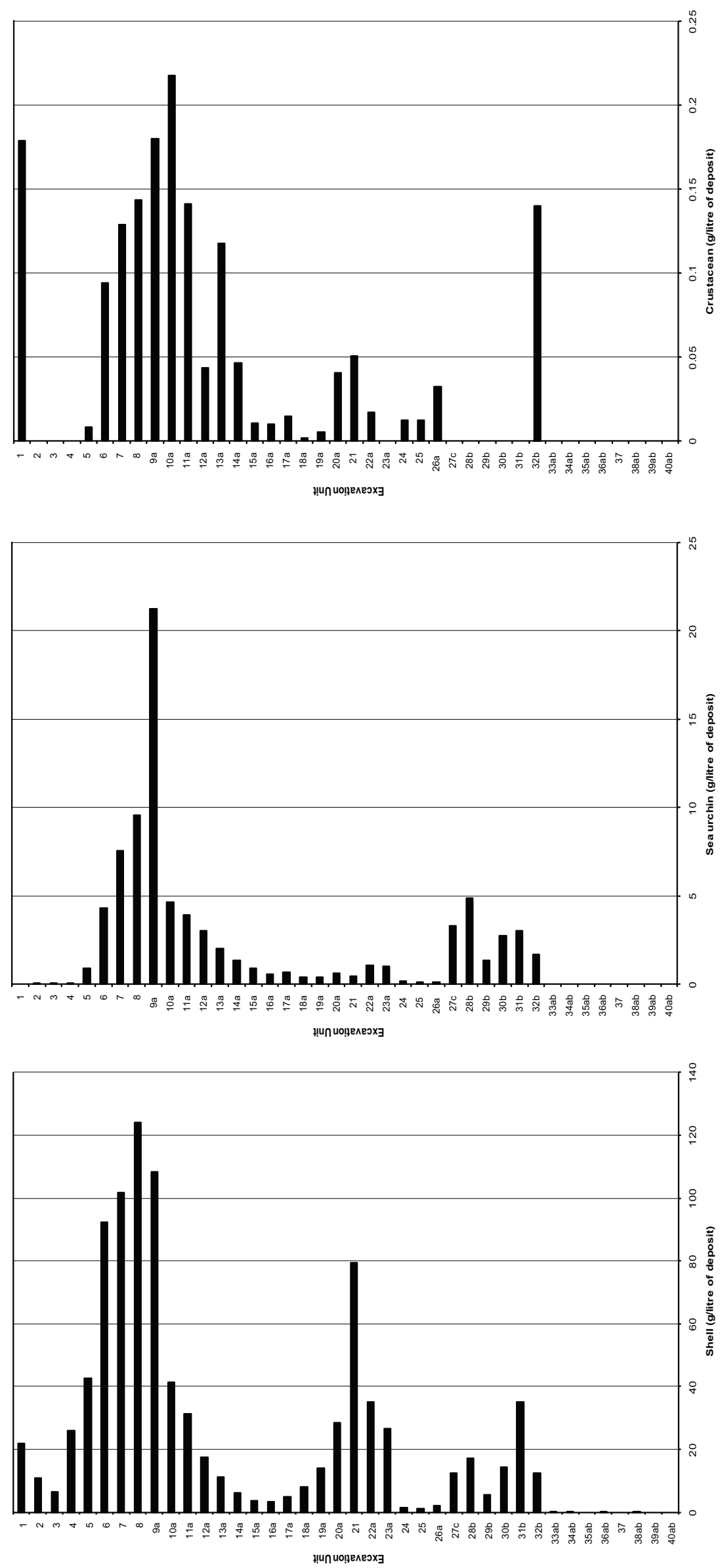

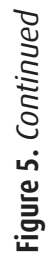


Table 1. AMS radiocarbon charcoal dates, Square A, Edubu 1. "Median probability of calibrated dates rounded to the nearest 50 years.

\begin{tabular}{|c|c|c|c|c|c|c|c|c|}
\hline $\begin{array}{l}\text { Lab. } \\
\text { code }\end{array}$ & Square & $\begin{array}{c}\text { XU } \\
\text { (find \#) }\end{array}$ & $\begin{array}{l}\text { Depth } \\
\text { below } \\
\text { surface } \\
\text { (cm) }\end{array}$ & $\begin{array}{l}\delta^{13} \mathrm{C} \% 0 \\
\pm 0.2\end{array}$ & $\begin{array}{l}{ }^{14} \text { C Age } \\
\text { (years BP) }\end{array}$ & $\begin{array}{c}\text { Calibrated } \\
\text { age BP } \\
68.3 \% 1 \sigma \\
\text { (probabilities) }\end{array}$ & $\begin{array}{c}\text { Calibrated } \\
\text { age BP } \\
95.4 \% 2 \sigma \\
\text { (probabilities) }\end{array}$ & $\begin{array}{l}\text { cal BP } \\
\text { circa: }\end{array}$ \\
\hline Wk-27302 & A & $13 b(3)$ & 28.5 & 74.7 & $2339 \pm 30$ & $\begin{array}{c}2335-2358 \\
(1.000)\end{array}$ & $\begin{array}{l}2318-2376(0.835) \\
2384-2459(0.165)\end{array}$ & 2350 \\
\hline Wk-27301 & $A$ & $22 \mathrm{a}(4)$ & 46.2 & 73.8 & $2440 \pm 30$ & $\begin{array}{c}2363-2419 \\
(0.338) \\
2428-2492 \\
(0.402) \\
2601-2608 \\
(0.034) \\
2641-2678 \\
(0.227)\end{array}$ & $\begin{array}{l}2355-2544(0.677) \\
2563-2571(0.010) \\
2586-2616(0.080) \\
2635-2700(0.233)\end{array}$ & 2500 \\
\hline Wk-27510 & B & $18(2)$ & 36.6 & 73.0 & $2531 \pm 30$ & $\begin{array}{c}2541-2590 \\
(0.383) \\
2615-2636 \\
(0.220) \\
2698-2738 \\
(0.397)\end{array}$ & $\begin{array}{l}2492-2601(0.470) \\
2608-2641(0.186) \\
2678-2744(0.344)\end{array}$ & 2600 \\
\hline Wk-27511 & $B$ & $27(1)$ & 56.7 & 72.9 & $2537 \pm 30$ & $\begin{array}{c}2543-2564 \\
(0.175) \\
2568-2587 \\
(0.131) \\
2616-2635 \\
(0.226) \\
2700-2740 \\
(0.467)\end{array}$ & $\begin{array}{l}2494-2599(0.427) \\
2610-2640(0.185) \\
2681-2746(0.388)\end{array}$ & 2650 \\
\hline Wk-27512 & $B$ & $29 a(1)$ & 71.1 & 73.1 & $2520 \pm 30$ & $\begin{array}{c}2507-2528 \\
(0.136) \\
2539-2593 \\
(0.425) \\
2614-2637 \\
(0.200) \\
2697-2725 \\
(0.239)\end{array}$ & $\begin{array}{l}2488-2644(0.711) \\
2665-2741(0.289)\end{array}$ & 2600 \\
\hline Wk-27514 & $C$ & $12 \mathrm{a}(4)$ & 29.0 & 73.2 & $2502 \pm 30$ & $\begin{array}{c}2498-2596 \\
(0.694) \\
2612-2623 \\
(0.074) \\
2628-2638 \\
(0.074) \\
2691-2714 \\
(0.158)\end{array}$ & $2470-2730(1.000)$ & 2600 \\
\hline Wk-27515 & $C$ & $17 a(2)$ & 40.3 & 73.1 & $2514 \pm 30$ & $\begin{array}{c}2503-2530 \\
(0.172) \\
2537-2594 \\
(0.442) \\
2614-2637 \\
(0.188) \\
2696-2720 \\
(0.197)\end{array}$ & $\begin{array}{l}2488-2644(0.722) \\
2653-2739(0.278)\end{array}$ & 2600 \\
\hline Wk-27516 & $C$ & $22(1)$ & 58.3 & 72.8 & $2546 \pm 30$ & $\begin{array}{c}2545-2561 \\
(0.129) \\
2573-2582 \\
(0.056) \\
2616-2635 \\
(0.221) \\
2701-2744 \\
(0.594)\end{array}$ & $\begin{array}{l}2497-2597(0.350) \\
2612-2639(0.182) \\
2689-2748(0.469)\end{array}$ & 2650 \\
\hline
\end{tabular}


Table 2. Marine shellfish MNI, Square A, Edubu 1.

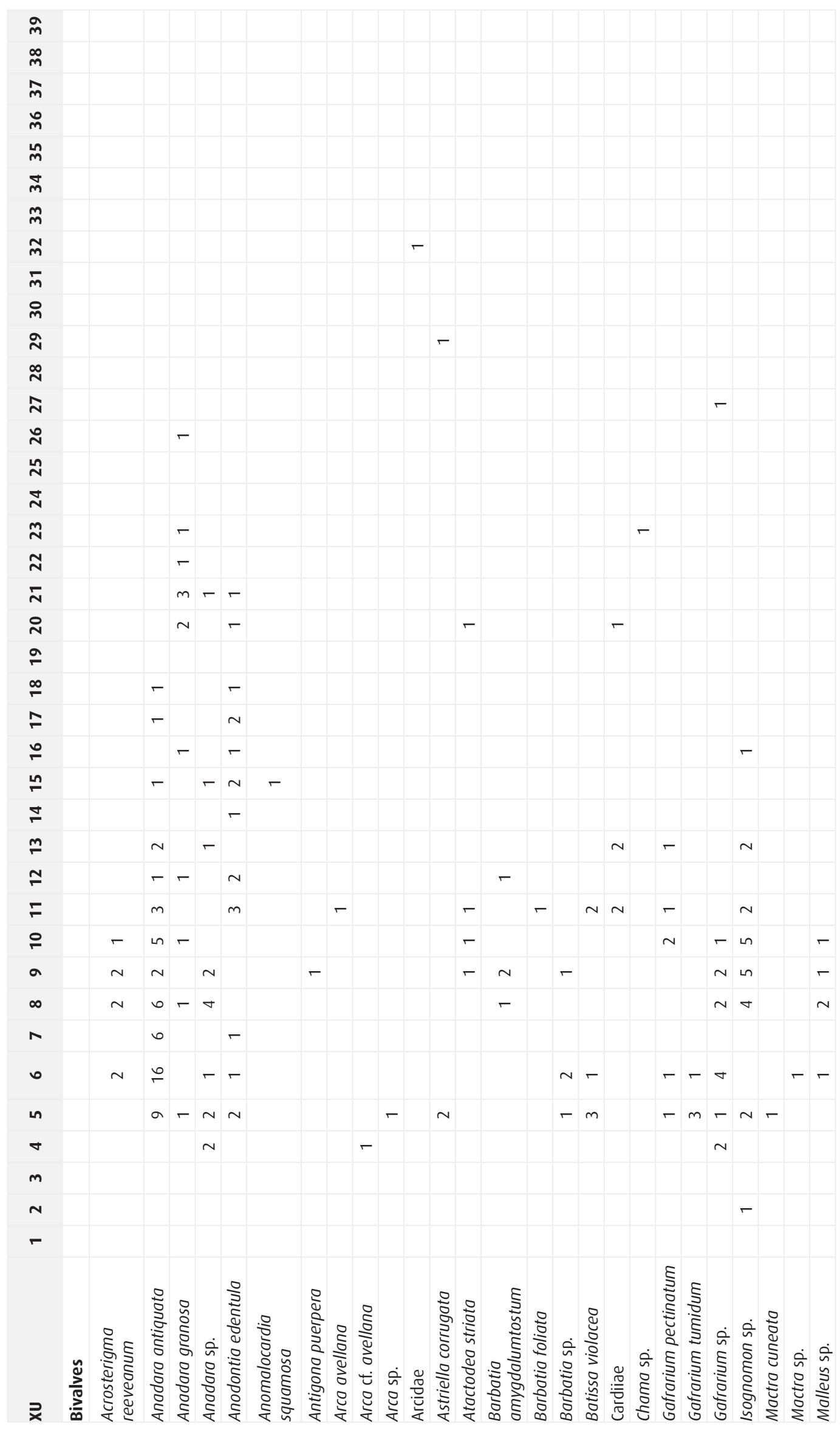


Table 2. Continued

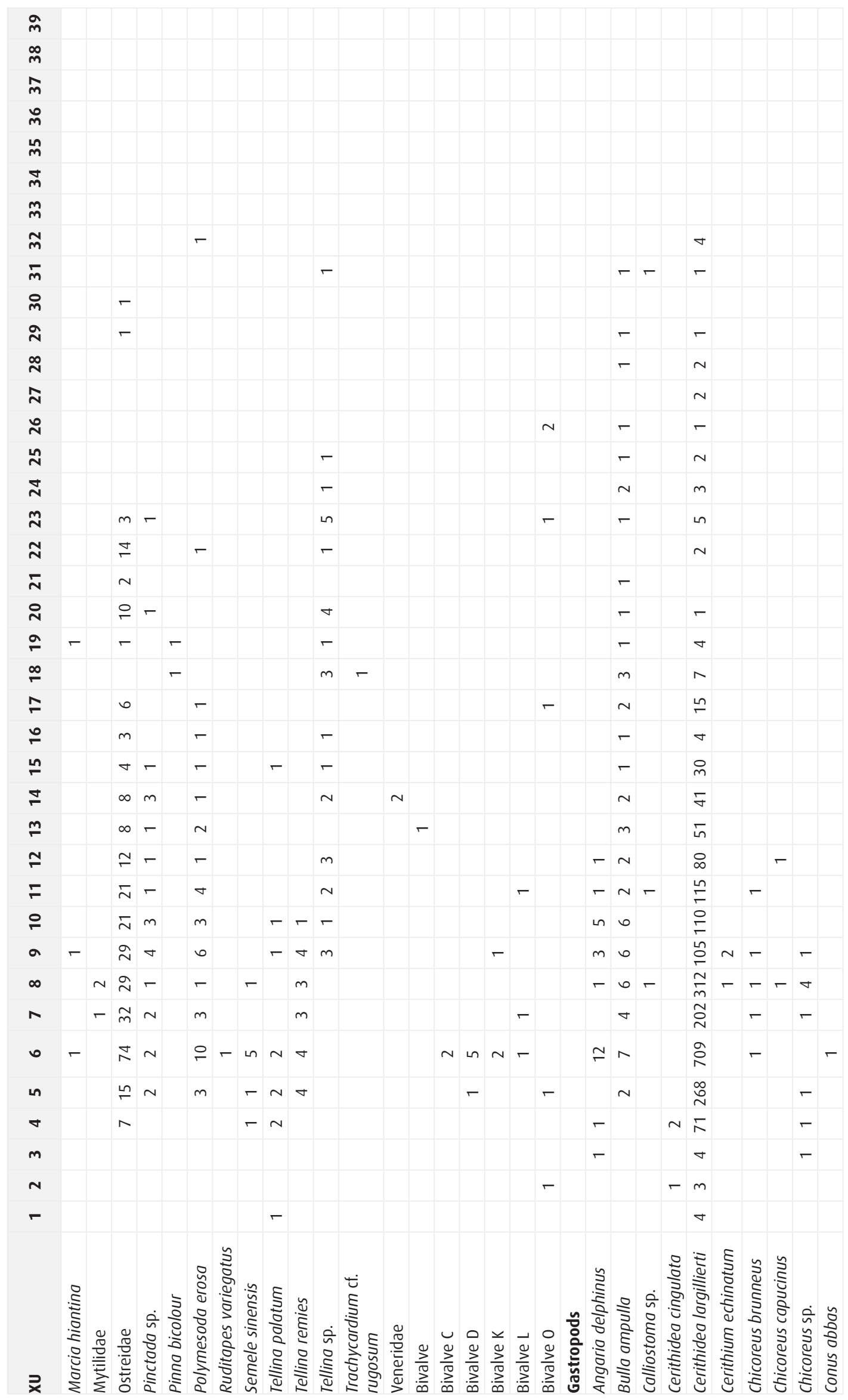




\section{Table 2. Continued}

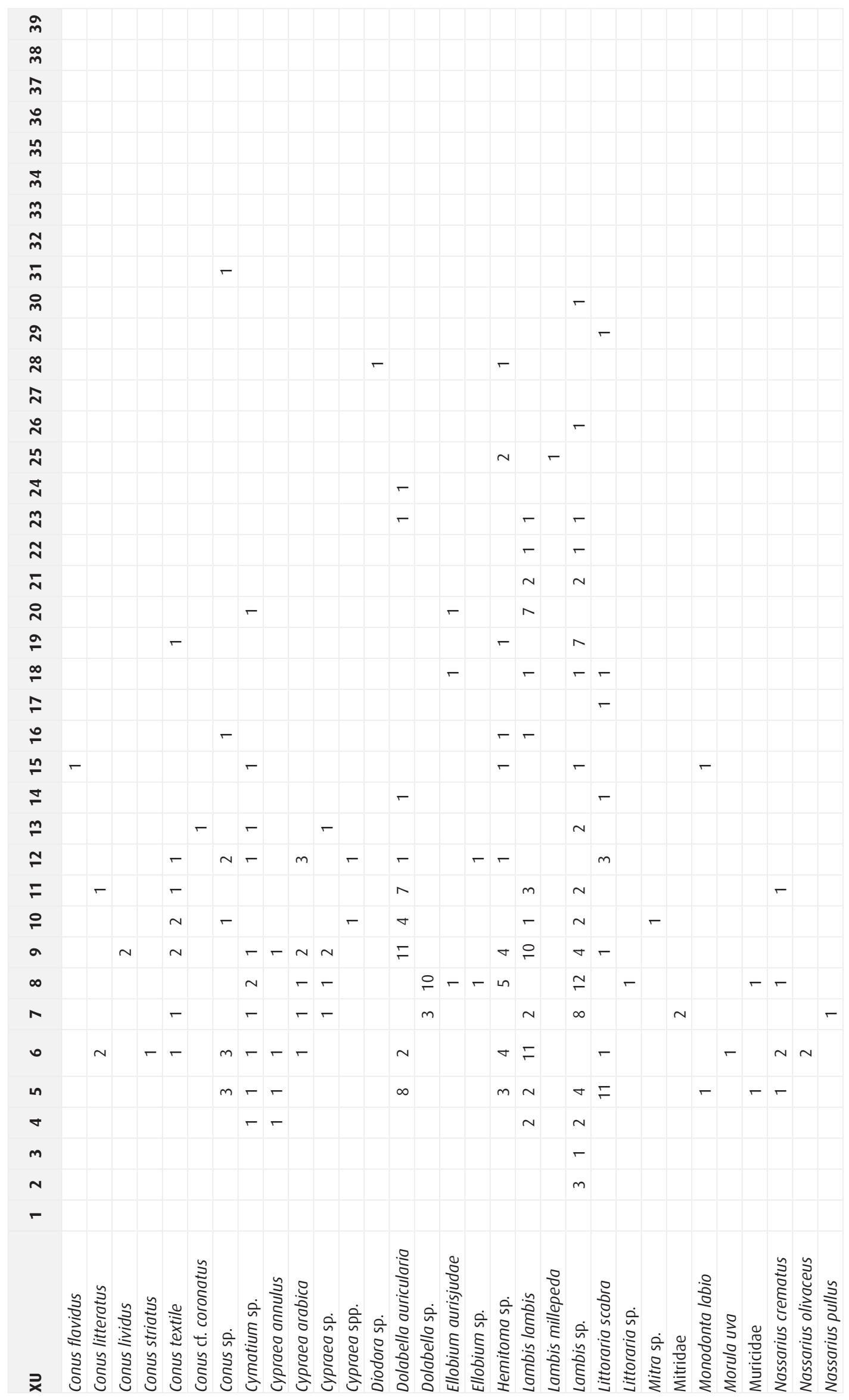


Table 2. Continued

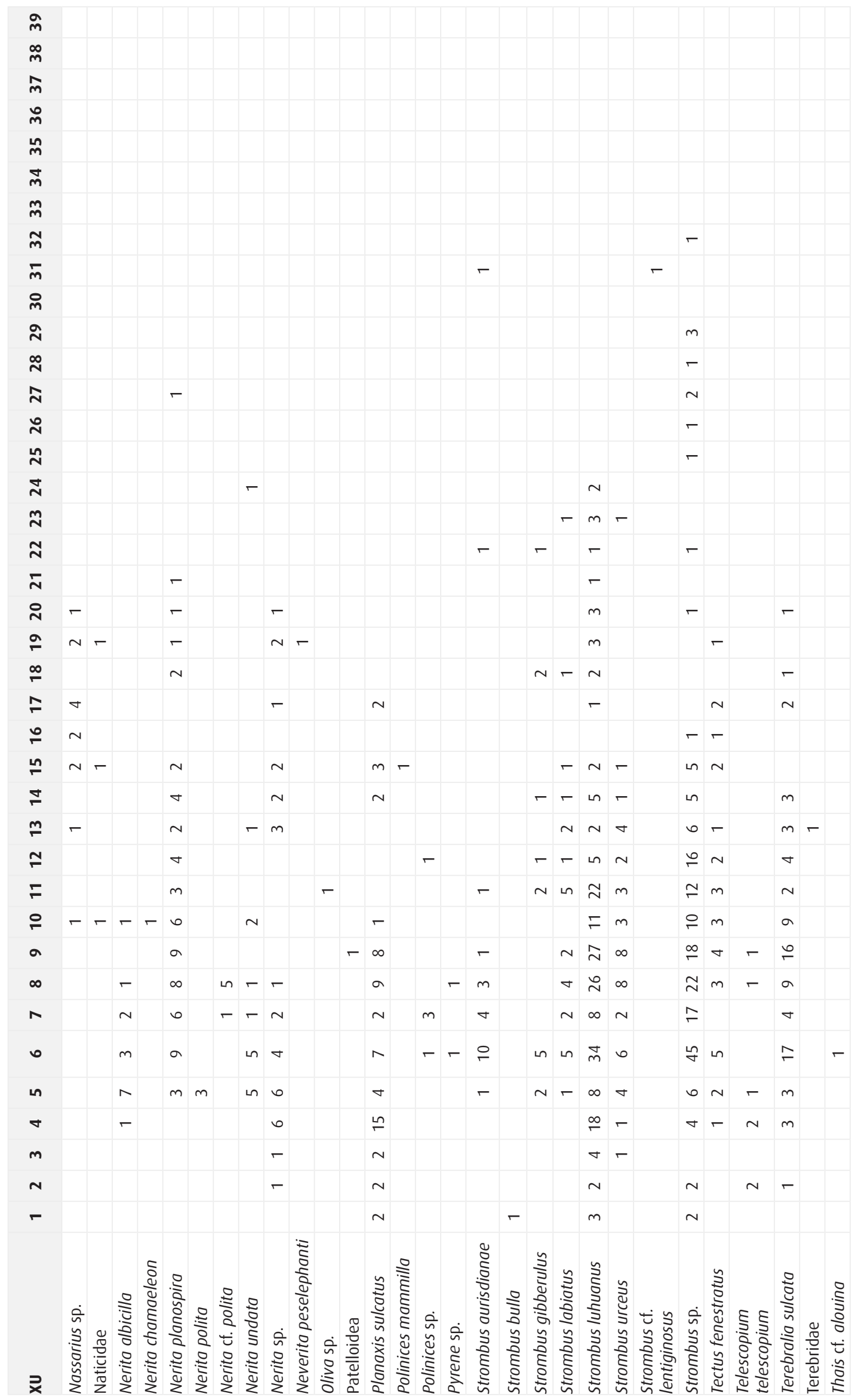


Table 2. Continued

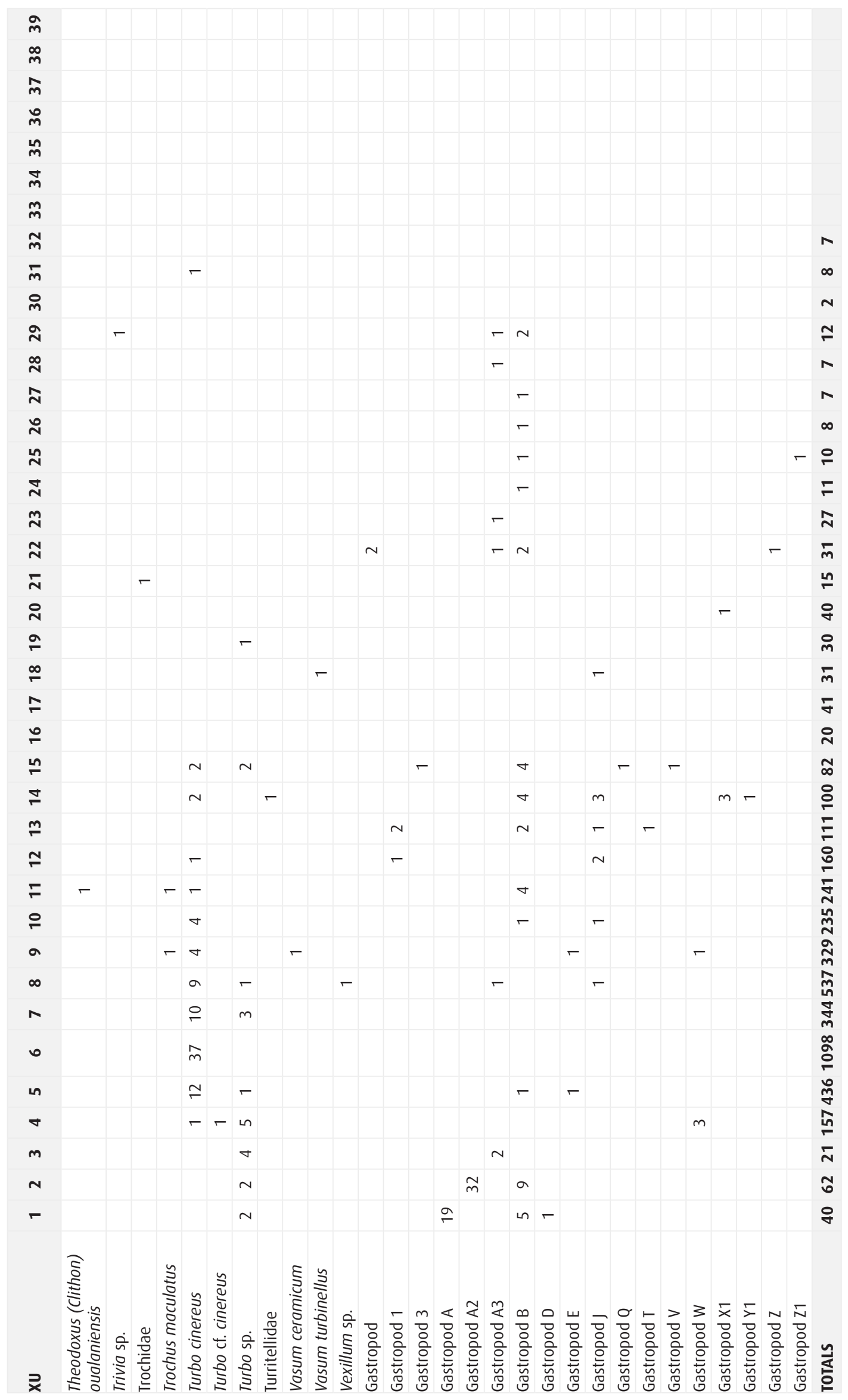


Table 3. Vertebrate bone NISP data, Square A, Edubu 1.

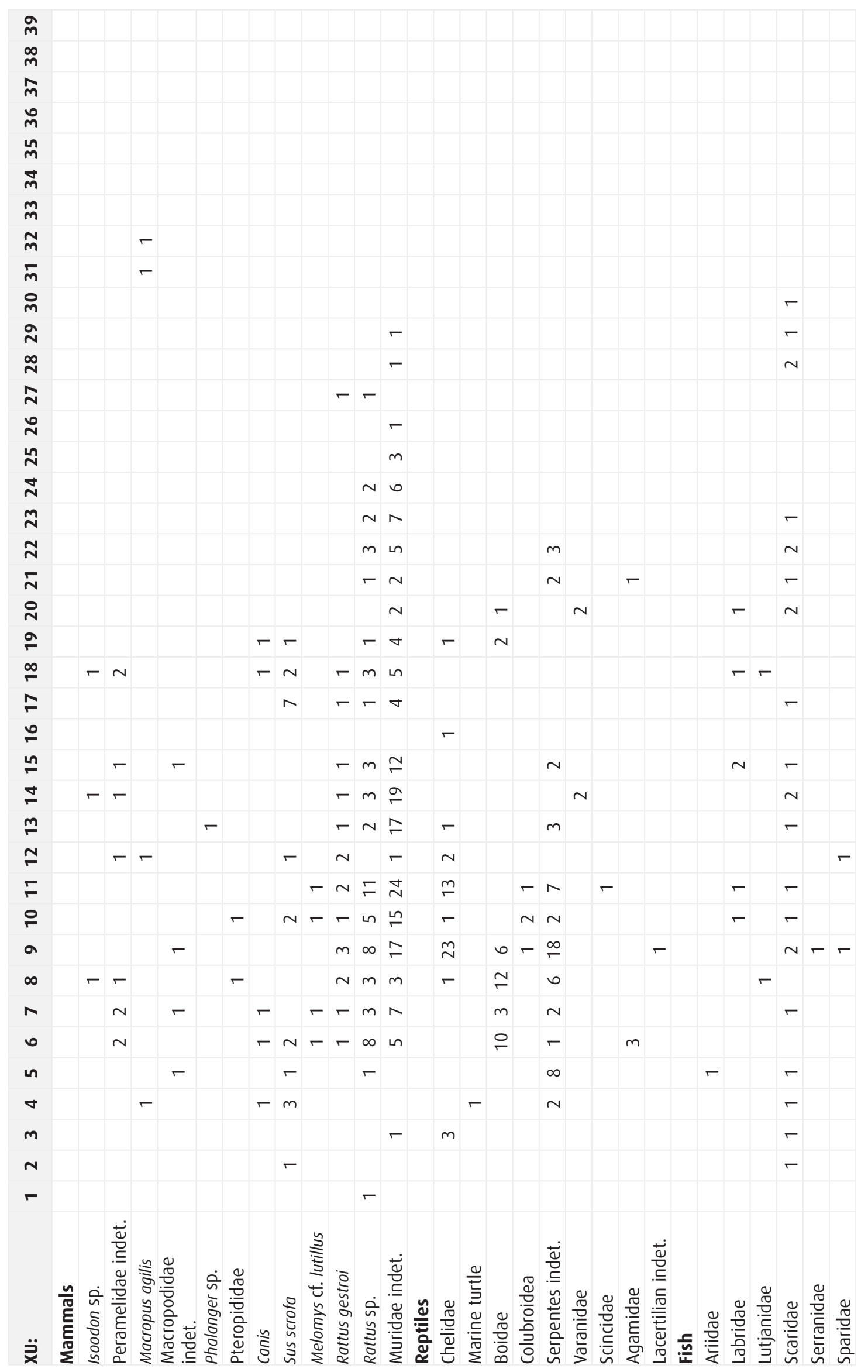


bivalves (4081.8 g), gastropods $(12,162.3 \mathrm{~g})$, chitons $(31.2 \mathrm{~g})$ and $7814.8 \mathrm{~g}$ of shell material that could not be identified to family, genus, or species level due to fragmentation and/or weathering. A total of 4260 individuals (MNI) was calculated for Square A (including unidentified bivalves and gastropods $<1.0 \mathrm{~cm}$ long), represented mostly by gastropods (MNI=3606) and to a lesser extent bivalves (MNI=654). Land snails (family Camaenidae) formed an insignificant part of the shell assemblage (1.8 g, MNI=3).

More than 140 different mollusc taxa were identified, represented by at least 45 bivalve taxa and 99 gastropod taxa (Table 2). Of these, species-level identifications were possible for $43 \%$ (by weight) of the total shell assemblage. The top five ranked bivalve species in terms of MNI abundance are: Anadara antiquata $(8.1 \%, \mathrm{MNI}=53)$, Polymesoda erosa $(6.0 \%, \mathrm{MNI}=39)$, Tellina remies (2.9\%, MNI=19), Anodontia edentula (2.8\%, MNI=18) and Anadara granosa $(2.0 \%, \mathrm{MNI}=13)$. These species represent only $22 \%$ (by MNI) of the bivalve assemblage, with 27 bivalve taxa represented by a MNI of $\leq 5$. The top five ranked gastropod species in terms of MNI abundance are: Cerithidea largillierti (59.6\%, MNI=2159), Strombus lubuanus (5.3\%, MNI=193), Turbo cinereus (2.3\%, MNI=84), Terebralia sulcata $(2.2 \%, \mathrm{MNI}=78)$ and Nerita planospira $(1.7 \%, \mathrm{MNI}=62)$. These taxa represent $71 \%$ (by MNI) of the gastropod assemblage, with 62 gastropod taxa represented by a MNI of $\leq 5$. A small proportion of the assemblage $(\mathrm{N}=214,5 \%)$ consists of intact small specimens (maximum length $<1 \mathrm{~cm}$ ), suggesting that only a relatively small proportion of the assemblage was of non-economic utility.

Environmental data are available for 76 species, with 52 of these restricted to a single environment type $(\mathrm{MNI}=2644)$. Preliminary analysis indicates that shells were obtained from a variety of different environments: mud (MNI=2233), rocks and rocky areas (MNI=209), seagrass $(\mathrm{MNI}=121)$, coral reef $(\mathrm{MNI}=25)$, sand $(\mathrm{MNI}=37)$, muddy sand $(\mathrm{MNI}=18)$ and mangroves $(\mathrm{MNI}=2)$. Muddy environments were the main targeted shellfishing location, with only minor differences in habitat preference through time.

Fish. Fish bone represents $18.3 \%$ of the bone assemblage (by weight) and formed a consistent component of the diet of peoples camping at Edubu 1 (Table 3). The most common taxon of marine fish in terms of NISP values is Scaridae (parrotfish), followed by very low representations of Labridae (wrasse), Sparidae (sea bream), Serranidae (groupers) and Lutjanidae (snapper). These fish could have been obtained from local open-water reef habitats fringing Caution Bay. The lack of fishhooks recovered from Edubu 1 points towards use of spears or nets as fishing technology. While most fish remains were restricted chronologically to $<2350-2500 \mathrm{cal} \mathrm{BP}$ in Square A, the deeper Scaridae bones in XUs 28-30 most likely date to 2600-2650 cal BP.

Marine turtle. The only marine turtle bone recovered from Square A was a fragment of phalanx in XU4 dating to younger than ca. $2350 \mathrm{cal} \mathrm{BP.}$

Crustacean and sea urchin. Crustaceans (mostly a number of different crab taxa) and sea urchins represent consistent subsistence items throughout the history of site occupation. While crabs were a minor dietary item, the considerable amounts of sea urchin body and spine fragments point to sustained exploitation. Crabs are available from a range of marine habitats (e.g. rocks, coral reefs, mangroves), with sea urchins restricted more to coral reef contexts. Both crabs and sea urchins were probably collected from the intertidal zone at low tide.

\section{Subsistence (terrestrial and freshwater)}

Most of the terrestrial bone recovered from Square A reflects the results of human hunting and on-site discard practices. That is, the assemblage comprises bones of known prey species, and there is a significantly high proportion of burnt bone. The fact that rodent bone tends to be less burnt than other mammal bones may indicate contributions of natural on-site rodent deaths. The highly fragmented nature of the bone assemblage suggests that mechanical attrition rather than chemical solution has been the major agent of degradation, pointing to 
substantial pre-depositional loss, perhaps caused by trampling and foraging by pigs and dogs. Furthermore, the unburnt bone is moderately degraded, suggesting a significant attrition of the original assemblage, with an unknown quantity of bone probably lost to post-depositional degradation.

Endemic mammals. The mammal remains include a range of medium- and small-sized species characteristic of local savannah and gallery rainforest habitats, both ground-dwelling taxa - Macropus agilis (Agile Wallaby), Isoodon sp. (possibly Northern Short-Nosed Bandicoot, Isoodon macrourus), and native rodents (e.g. Melomys cf. lutillus, Rattus gestroi); and treedwelling taxa - Phalanger sp. (possibly Southern Lowland Cuscus, Phalanger intercastellanus) and Pteropididae (flying fox). While most of these mammals were recovered from upper levels in Square A, dated to <2350-2500 cal BP, some Agile Wallaby remains were found in the lower levels dated to 2600-2650 cal BP.

Introduced pig and dog. Pig remains were found in nine XUs between XU2 and XU19a dated to between $<2350$ and $2500 \mathrm{cal} \mathrm{BP}$. Whether pig bones occur in the $2600-2650 \mathrm{cal} \mathrm{BP}$ levels of Squares B and C remains to be determined. Most pig bones in Square A are small fragments of teeth, but XU17a and XU19a each produced larger fragments of dentaries with teeth. Dog remains were also restricted to the upper levels of Square A (XUs 4, 6, 7, 18 and 19), dating to between $<2350$ and $2500 \mathrm{cal} \mathrm{BP}$. There is no evidence of the introduced Pacific rat (Rattus exulans).

Reptiles. A range of reptile taxa was recovered from upper levels of Square A, dated to $<2350-2500 \mathrm{cal}$ BP. The most common are pythons (Boidae) and fanged snakes (Colubroidea), with minor representations of lizards such as goannas (Varanidae), dragons (Agamidae) and skinks (Scincidae). All of these reptiles are available from local savannah and grasslands.

Birds. While no bird bone was recovered from Square A, a few bird eggshell fragments $(0.01 \mathrm{~g})$ were found in XU23. These fragments are thin-walled and are consistent in character with megapode eggs. Clearly, hunting of birds for subsistence was of little interest to the occupants of Edubu 1.

Freshwater turtle and fish. Freshwater turtle (Chelidae) bone forms an inconsistent component of the faunal assemblage down to XU19a, dating to $<2350-2500$ cal BP. In contrast, bones of Ariidae (catfish) were identified only in a single level (XU5), indicating that catfish formed an insignificant component of the diet for the site inhabitants. Both the turtle and catfish remains indicate minor exploitation of nearby estuaries and/or freshwater creeks.

\section{Ceramics}

In Square A, ceramic sherds were recovered from XUs 1 to 32, dating from $<2350 \mathrm{cal}$ $\mathrm{BP}$ to at least $2600 \mathrm{cal} \mathrm{BP}$ (Figure 5). A total of 33 decorated sherds, excluding red slipping, was recovered. The ceramic sherds from XUs 1 to 15 are mainly plainwares, with decoration limited mostly to red-slipping. These upper-level ceramics date to younger than $2500 \mathrm{cal} \mathrm{BP}$ and fall outside the stylistic and chronological parameters of Lapita pottery found elsewhere at Caution Bay (McNiven et al. 2011). In contrast, decorated sherds found below XU16 exhibit features that are broadly characteristic of terminal Lapita ceramic assemblages elsewhere at Caution Bay, but also show stylistic signs that they were by then transforming out of Lapita into post-Lapita assemblages. Descriptions of all the ceramics containing body decorations other than red slip follow:

Vessel shapes. Sherds from three separate vessels are large enough to reveal information about vessel shapes:

1. A wide, shallow dish with a very slightly everted to vertical rim (orientation angle $=5$; see David et al. 2009:Figure 4 for definitions of pottery terms) and orifice diameter of 52 
$\mathrm{cm}$. It is made up of four conjoining sherds from XU16a and XU18a. The lip is flat and of a fairly uniform $10.6 \mathrm{~mm}$ width. The rim is typically $35.4 \mathrm{~mm}$ deep to its point of greatest curvature, where it then becomes the body of the dish. Plain sherds excavated from these same XUs are likely to also conjoin (Figure 6:top).

2. A small bowl with a slightly inverted, near-vertical rim (orientation angle $=355^{\circ}$ ). It consists of a set of three conjoining sherds from XU20a, two sets of two conjoining sherds from XU20a, and three individual sherds from XU19a and XU20a. The lip is rounded and of a uniform 6.7-6.8 $\mathrm{mm}$ width. The rim is typically $34.4 \mathrm{~mm}$ deep, after which it gently curves into the bowl body. Plain sherds excavated from these same XUs are likely to conjoin (Figure 6:bottom).

3. An indirect everted pot of unknown orientation angle (as there are no lip sherds). The aperture at the neck (the most constricted point at the base of the rim) is approximately $20 \mathrm{~cm}$ wide (internal measurement). At $5.9 \mathrm{~mm}$ thickness, the pot wall at the neck - the thickest part of the pot - is noticeably thin for what appears to be a moderately large jug or bowl (Figure 7e).

Body Decorations. The body decorations employed on the sherds described here can be divided into nine categories:

1. Comb dentate-stamped triple-triangles (note: throughout our work on the Caution Bay ceramics, we differentiate between tools used to make decorations - e.g. comb or shell, and the decorations themselves - e.g. indentations, which could be made by a number of tined or toothed tools such as combs or shells. Hence, we specify both tool [here comb] and decorative design [here dentate-stamped]). Two closely spaced comb dentatestamped parallel lines curve around the pot a short distance below the top edge of the lip. These horizontal lines act as the upper margin of down-pointing dentate-stamped triangles, whose other two sides each have three parallel lines. Dentate-stamped triangles of this kind are repeated across the pot as a motif row. Twenty sherds, consisting of nine unconjoined sherds, plus 11 which conjoin into four sets, occur of this motif type. One conjoining set of four sherds, with internal surfaces red-slipped, comes from XU16a and XU18a and makes up part of one shallow dish (vessel shape 1 above); the other sherds, all coming from XU19a and XU20a, either conjoin or are very likely to have come from a small bowl with slightly inverted rim (vessel shape 2 above). The chrono-stratigraphic distribution, size, shape and surface texture of the sherds with this kind of decoration indicate that they all probably come from only two different vessels (Figure 6). Examples of similar (but not identical) decorative technique and design in confirmed late-Lapita sherds occur at Honiavasa on the edge of the Roviana Lagoon in New Georgia (Solomon Islands), illustrated in Felgate (2001:Figure 3 items HV.2.464, HV.4.175). However, the Edubu 1 sherds appear to represent a structurally simpler pattern of repeated triangles a short distance below the lip.

2. Irregular comb dentate-stamped horizontal lines. Two conjoining sherds, from XU12a and XU13a, contain a horizontal line below two other sub-horizontal lines meeting at a point along the rim. The lines consist of irregular, uneven comb dentate stamping.

3. Dentate-stamped rectilinear maze. A single non-rim sherd of this kind has been found from XU20a (Figure 7a). It is akin to established Lapita motifs such as the ones found 
at site FAAH on the Willaumez Peninsula (New Britain) and illustrated in Specht and Torrence (2007:Figure 11b, 11c, 11d).

4. Dentate-stamped rectilinear lines on lip. A single thickened rim sherd is decorated with repeated sets of five parallel dentate-stamped lines separated by pairs of perpendicular lines. It was a surface find at the base of the slope along the northern edge of the site (Figure 7b).

5. Parallel wiggly lines created from shell valve end-impressions along the rim. Two such sherds come from XU6 to XU9b (Figure 7c).

6. Dentate-stamped triple-angled lines on lip. The outer edge of the lip is notched at regular intervals. The lip is noticeably thickened. A single sherd of this kind has been found from XU19a (Figure 7d).

7. Wiggly lines created from shell valve end-impressions to form triangles arced around a central design. Three conjoining sherds of this kind have been found, and are reminiscent of the banding triangles commonly found on Lapita ceramics (Figure 7e). Shell impressions are a feature of late-Lapita assemblages elsewhere in island Melanesia (e.g. Kirch 1997:155). These sherds were exposed during bulldozer construction works immediately following the archaeological excavations.

8. Row of lenticular, probably stick, side impressions on two body sherds from XU9b and XU18a.

9. Row of fingernail impressions on a body sherd from XU18b.

The Edubu 1 Square A decorated ceramic sherds include techniques and designs akin to terminal Lapita (in particular comb-impressed dentate stamping involving the use of more open, broad-tined combs; wiggly lines of shell end-impressions to create triangular designs separated by impressed rows; an interlocking rectilinear maze; and shallow stick-like impressions along lip edges). However, they also contain features more reminiscent of the immediate post-Lapita period in the Caution Bay region: there is a simplification of decorative forms particularly attested to by a predominance of simple geometric designs such as triple-lined dentate-stamped triangles below double rows a short distance below the lip, and a diminished area of surface decoration. The Edubu 1 Square A ceramic decorations imply a terminal-Lapita assemblage, as they are transforming out of the Lapita design system: they are still too similar to late Lapita to categorically classify them as something else, while at the same time indicating a repeated theme of reduction in design complexity and diminution of decorated area, indicative of the immediate post-Lapita period. This is entirely consistent with the radiocarbon determinations, and with the Lapita and post-Lapita ceramics from other sites at Caution Bay, which would place the ceramic assemblage from below XU13 as relating to that period when terminal Lapita (ca. $2500 \mathrm{cal} \mathrm{BP}$ ) is transforming into post-Lapita, indicating the initial opening and breakdown of the Lapita decorative system.

\section{Stone artefacts}

The stone artefact assemblage from Square A comprises flaked artefacts (flakes, retouched flakes and cores), a flaked and ground adze, and an anvil. Nearly all ( $\mathrm{n}=2546,98 \%)$ artefacts were made from chert, which is locally available as small and large nodules across the Caution 

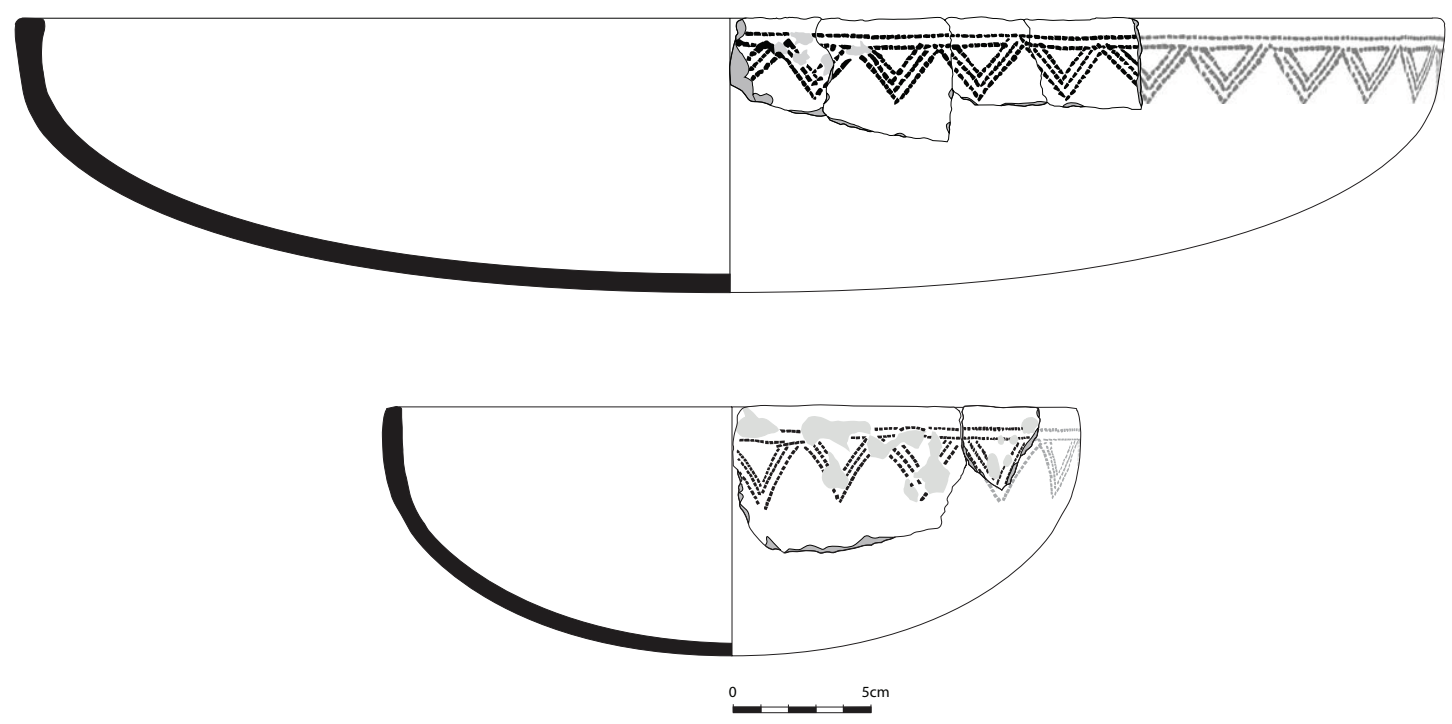

Figure 6. Ceramic bowls from Square A, Edubu 1, dating to 2350-2500 cal BP. Top: XUs 16-18. Bottom: XUs 19-20.

Bay landscape and the Port Moresby region more generally (Table 4) (Glaessner 1952:6667; Mabbutt et al. 1965; Davies and Smith 1971:3303). In terms of fracture types for chert, most $(83 \%)$ are flakes (complete and broken) $(n=2115)$, followed by flaked pieces $(n=374)$, cores $(n=22)$ and other $(n=34)$. The majority $(57 \%)$ of chert artefacts reveal evidence of heat alteration (pot lid scars) from contact with fire - either hearths or natural landscape fires when the site was unoccupied. All of the 22 chert cores were reduced by freehand percussion, with no evidence of anvil-resting or bipolar reduction. That cores made of high-quality chert were reduced further than cores made from poor-quality chert is indicated by differences in mean core weight (15 g and $67 \mathrm{~g}$ respectively), mean core length $(29 \mathrm{~mm}$ and $48 \mathrm{~mm})$, mean number of platforms (3.5 and 2.5) and mean number of flake scars (nine and four). The small size of chert cores is reflected in the small size of complete chert flakes, which range in length from $2 \mathrm{~mm}$ to $26 \mathrm{~mm}$ (mean $=9.3 \mathrm{~mm}$ ). Only $8 \%$ of complete chert flakes and $1.5 \%$ of chert flake platforms exhibit cortex, suggesting strongly that the early stages of core reduction took place elsewhere. The 12 obsidian artefacts are small flakes (mean weight, $0.3 \mathrm{~g}$; mean length, $8 \mathrm{~mm}$; length range, $4 \mathrm{~mm}-16 \mathrm{~mm}$ ), showing no signs of bipolar reduction. The nearest source of obsidian is West Ferguson Island located $500 \mathrm{~km}$ to the east (Irwin and Holdaway 1996).

More formally manufactured implement types include retouched flakes and an adze. Retouched flakes comprise only $2.2 \%$ of the lithic assemblage and are represented by chert $(\mathrm{n}=55)$ and chalcedony $(\mathrm{n}=1)$. As with chert, chalcedony outcrops in the Port Moresby region (Glaessner 1952:66). The mean length of retouched chert flakes $(14.8 \mathrm{~mm})$ is larger than the mean length of unretouched chert flakes, indicating selection of larger chert flakes for manufacture into curated implements. A flaked and ground adze was recovered from XU20a (Figure 8). It is manufactured from volcanic stone (possibly basalt) and weighs $154.9 \mathrm{~g}$. An anvil (also made from volcanic stone, possibly basalt) was recovered from XU2. The adze and anvil were likely imports, given that the nearest major outcrops of basalt are located 80-100 $\mathrm{km}$ to the northwest and southeast of Port Moresby (Glaessner 1952; Pieters 1978; Smith and Milsom 1984:165).

Whereas chert flakes were used throughout the history of site use, back to at least $2650 \mathrm{cal}$ $\mathrm{BP}$, obsidian artefacts have a more restricted occurrence in XUs 3 to 15 , dating between $<2350$ and $2500 \mathrm{cal}$ BP. While the adzes was recovered from the more recent levels, the lack of these implements in 2600-2650 cal BP levels may simply reflect issues of rarity and sampling. 
A

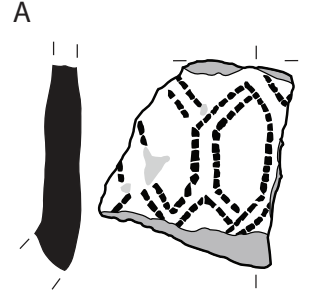

D

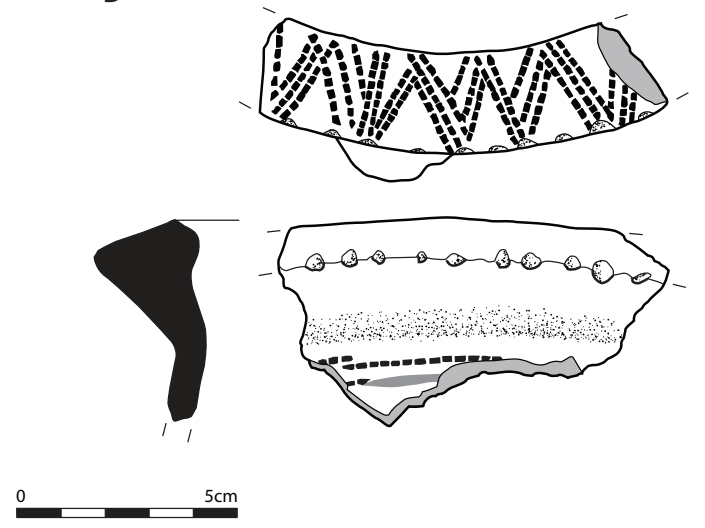

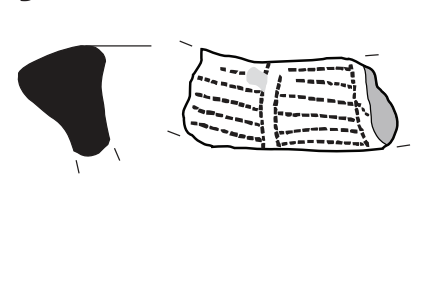

E
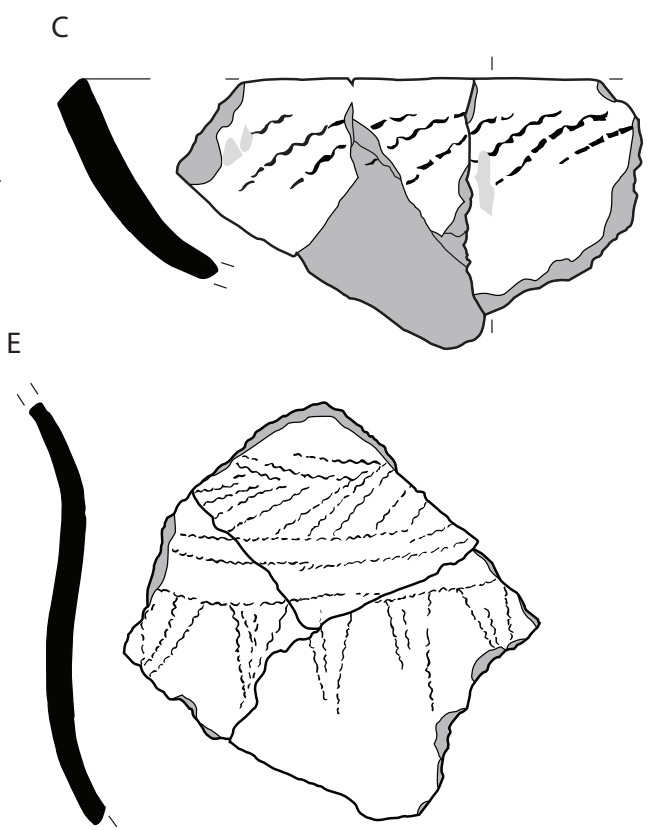

Figure 7. Decoration styles at Edubu 1 Square A. A: Dentate-stamped rectilinear maze dated to 2350-2500 cal BP. B: Dentatestamped rectilinear lines on lip dated to 2350-2500 cal BP. C: Shell valve end-impressions on rim dated to <2350 cal BP. D: Dentate-stamped triple-angled lines on lip dated to 2350-2500 cal BP. E: Shell valve end-impressed triangles arced around central design.

\section{Shell artefact}

A fragment of a shell ring was recovered from XU13, dating to $2350 \mathrm{cal}$ BP (Figure 9). The ring is approximately $30 \%$ complete and is finely made from what appears to be cone shell (Conus sp.). The surface of the ring exhibits smoothing and shaping by grinding. The ring is 10.5-10.7 mm high, 5.0-5.5 $\mathrm{mm}$ wide, and would have been $9 \mathrm{~cm}$ diameter (measured on the outside of the shell) when complete. Based on ethnographic information from the Port Moresby region, the shell ring may have been used as a body adornment and/or exchange valuable (Seligmann 1910).

\section{Implications for Port Moresby regional land-use history}

\section{Extending the 2000 cal BP barrier}

Before our Caution Bay study, the earliest evidence for people in the Port Moresby region was found at three sites - Nebira 4, Eriama 1 and Loloata Island. Nebira 4 is an open site located atop a low hill immediately north of Port Moresby, some $11 \mathrm{~km}$ inland from the coast. Excavations by Jim Allen in 1969 and 1970 revealed a $2.6 \mathrm{~m}$ cultural deposit of stone artefacts, shell artefacts and pottery (including red-slipped wares), along with bone and shell food remains (Allen 1972). Charcoal radiocarbon dates of $1760 \pm 90 \mathrm{BP}$ and $3340 \pm 160 \mathrm{BP}$ were obtained from Level 14, but well above basal cultural materials (Level 18). While Allen (1972:120) remarked that '[n]o archaeological reason can be given for this [dating] discrepancy', he rejected the earlier date, given the pottery assemblage similarities between Nebira 4 and the Oposisi site on Yule Island in the Gulf of Papua dated by Ron Vanderwal to 2000 years ago (cf. Vanderwal 1973). Eriama 1 is a small rockshelter located northeast of Port Moresby and 7.5 $\mathrm{km}$ from the sea. Excavations by Sue Bulmer in 1969 revealed a $0.9 \mathrm{~m}$ cultural deposit, with the lowest layer containing 'red slip pottery' and producing a charcoal radiocarbon date of $1930 \pm$ $230 \mathrm{BP}$ (ca. $1850 \mathrm{cal} \mathrm{BP}$ ) (Bulmer 1975:56). Loloata Island is located $15 \mathrm{~km}$ southwest of Port Moresby and $1 \mathrm{~km}$ from the mainland. A 'shell sample from the lower midden layer' produced 

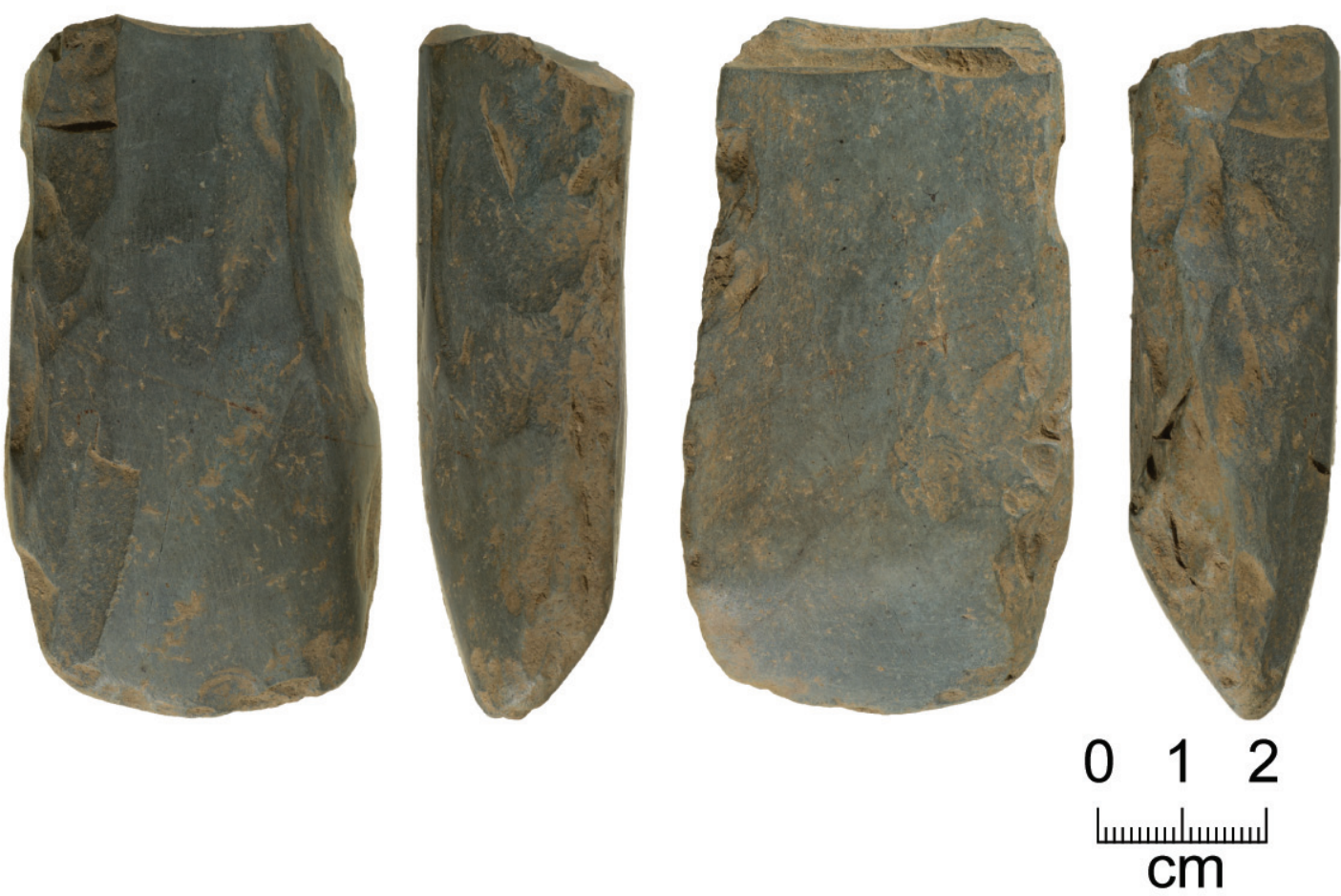

Figure 8. Adze from XU20a, Square A, Edubu 1, dating to between 2350 and 2500 cal BP.
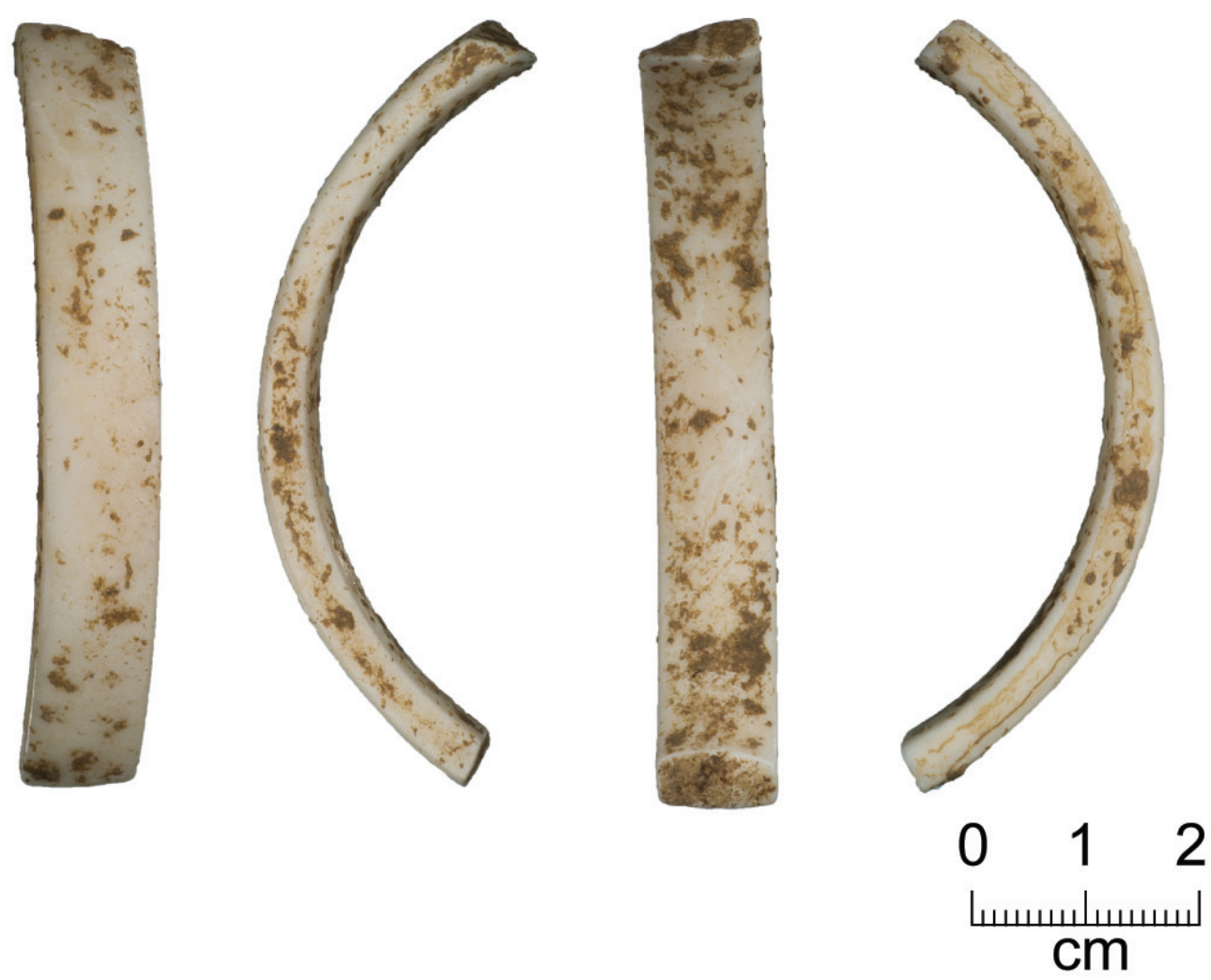

Figure 9. Shell ring from XU13, Square A, Edubu 1, dating to 2350 cal BP. 
Table 4. Stone artefact raw materials, Square A, Edubu 1.

\begin{tabular}{|c|c|c|c|c|}
\hline Raw material & $\#$ & $\%$ & Wt (g) & $\%$ \\
\hline Chert & 2546 & 98.2 & 1414.2 & 79.6 \\
\hline Chalcedony & 19 & 0.7 & 4.5 & 0.3 \\
\hline Obsidian & 12 & 0.5 & 3.1 & 0.2 \\
\hline Volcanic (basalt?) & 9 & 0.3 & 345.1 & 19.4 \\
\hline Siliceous sandstone & 2 & 0.1 & 0.1 & $<0.1$ \\
\hline Quartz & 2 & 0.1 & 0.1 & $<0.1$ \\
\hline Quartzite? & 1 & $<0.1$ & 9.3 & 0.5 \\
\hline $\begin{array}{l}\text { Fine-grained } \\
\text { sedimentary }\end{array}$ & 1 & $<0.1$ & 0.2 & $<0.1$ \\
\hline Fine-grained igneous & 1 & $<0.1$ & 0.1 & $<0.1$ \\
\hline Totals: & 2593 & 100 & 1776.7 & 100 \\
\hline
\end{tabular}

a radiocarbon age of $2300 \pm 100 \mathrm{BP}$ (ca. $1900 \mathrm{cal} \mathrm{BP}$ ) associated with 'red-slipped pottery' (Sullivan and Sassoon 1987:7). Based on site survey and excavation data, Allen (1977a:447) hypothesised that 'the existing archaeological evidence suggests the rapid occupation of both the coast and hinterland by pottery manufacturing people around 2,000 years ago'.

Recent excavation results from Caution Bay demonstrate that pottery-using (Lapita) peoples settled the Port Moresby region by 2900 cal BP, with pre-ceramic occupation extending back to at least $4200 \mathrm{cal} \mathrm{BP}$ (McNiven et al. 2011). As such, people settled the Port Moresby region well before the previously hypothesised $2000 \mathrm{cal} \mathrm{BP}$ for an initial migration by ceramicists to the region. Indeed, Edubu 1 was mostly, if not entirely, occupied before 2000 cal BP, between $<2350 \mathrm{cal} \mathrm{BP}$ and $2650 \mathrm{cal}$ BP. This expanded chronology for settlement of the region is not unexpected, given that Kukuba Cave, located $100 \mathrm{~km}$ along the coast northwest of Port Moresby, dates back to 4000 years ago (Vanderwal 1973). Indeed, it is probable that a human presence has been in the region since the Pleistocene, given archaeological evidence for well-established populations 49,000 years ago at Kosipe, located in the Owen Stanley Ranges $70 \mathrm{~km}$ north of Port Moresby (Fairbairn et al.2006; Hope 2009; Summerhayes et al.2010), and in the Papuan Gulf lowlands to the west by at least 13,000 years ago (David et al. 2007).

\section{Terminal Lapita settlement expansions}

Edubu 1, with terminal/transforming Lapita deposits, demonstrates that new Lapita sites were actively established at Caution Bay hundreds of years after the original arrival of Lapita peoples at $2900 \mathrm{cal} \mathrm{BP}$ (McNiven et al. 2011). Clearly, Caution Bay hosted a dynamic and developing community of Lapita peoples, with some sites such as Bogi 1 located $2.8 \mathrm{~km}$ westnorthwest of Edubu 1 spanning the full temporal extent of Lapita occupation at Caution Bay for 400 years between 2900 and $2500 \mathrm{cal} \mathrm{BP}$, and other sites such as Edubu 1 showing more temporally restricted Lapita occupation of less than 200 years (and possibly less than 100 years) between 2650 and 2500 cal BP. Significantly, Bogi 1 site, located downslope from Edubu 1 on the nearby shoreline of Caution Bay, reveals a major burst of activity at $2500-2650 \mathrm{cal}$ BP (McNiven et al. 2011). The fact that Lapita sites located on both the shoreline and $1 \mathrm{~km}$ inland exhibit synchronous increases in site activity at 2500-2650 cal BP indicates broad-scale social linkages across what is clearly a complex and integrated community of Lapita peoples at Caution Bay, and that probably also involves local non-Lapita populations. While it is possible that both Bogi 1 and Edubu 1 were used by similar peoples as part of seasonal movements, the fact that both sites show synchronous increases in cultural discard indicates at the very least greater human activity and most likely more people living in the area. 


\section{Marine subsistence and terrestrial hunting}

The lower sediment levels at Nebira 4 revealed exploitation of marine and terrestrial animals. Terrestrial animals include pig, dog and wallaby (Macropus agilis), while marine animals include turtle, dugong, fish (mostly estuarine catfish) and shellfish (mostly reef-dwelling Chama sp. and Strombus spp.). Interestingly, bandicoot and bird, which were present in upper levels, were not present in lower levels of Nebira 4. Allen (1972:123) concluded that early immigrants to the Port Moresby region possessed an 'economy based on mixed hunting, agriculture and fishing'. Yet it is clear that subsistence practices of early occupants at Nebira 4 focused more on aquatic animals than land animals, with fish accounting for $50 \%$ of bone assemblages (Allen 1972:118). While nearly all fish (92\% of MNI) in Levels 16-19 were catfish, Allen (1972:118) argued that these high-saltwater-tolerant fish were probably 'caught in estuarine conditions' and not more characteristic riverine contexts located adjacent to the site (cf. White and O'Connell 1982:203). Bulmer (1971:57) concurs and commented that the 'earliest occupants of Nebira 4 had a predominantly maritime economy, with enormous quantities of fish, sea mammals, and shell fish consumed' (see also Bulmer 1979:18). Allen (1977b) acknowledged the early focus on marine resources, stating 'the subsistence patterns of these early migrants was oriented much towards the sea and the exploitation of sea resources, but that land hunting also contributed to the diet'. The nature of subsistence remains in the lower levels of Eriama 1 is difficult to determine given the disturbed stratigraphy and incomplete reporting of finds. However, remains from 'Crevice Layer 3' (from where the early date was obtained) revealed low amounts of shell (mangrove and freshwater species) and possibly small quantities of mammal (mostly wallaby) and fish bone (Bulmer 1978:Table 7.6, Appendix 7.2). The lower midden on Loloata Island contained 'abundant [marine] shell' and specialised marine subsistence is implied (Sullivan and Sassoon 1987:3).

Faunal remains from Nebira 4 and Eriama 1 reveal that the maritime peoples living in the Port Moresby region around 2000 years ago consumed pigs and wallabies. While wallabies were clearly hunted in the wild, Allen (1977b:37) hypothesises that pigs may have been 'husbanded rather than hunted in their feral state'. Yet the question remains as to what extent hunting of terrestrial animals reflected the location of both sites some distance from the coast $(11 \mathrm{~km}$ and $7.5 \mathrm{~km}$ inland respectively). Interestingly, early ethnographic accounts from the late 19th century mention pigs and highlight the importance of wallaby hunting, particularly among the Koita, and the importance of fish, particularly among the Motu (Stone 1876:60; Lawes 1879:373, 375; Chalmers 1887:14-15; Turner 1878:482, 487, 495; see also Allen 1977a, 1991; Oram 1977; Vasey 1982). Turner (1878:481) observed that 'the food of the Motu consists principally of wallaby, fish, yams, bananas, cocoa-nuts, and sago' (see also Stone 1876:47). Today, local people of Caution Bay hunt Agile Wallaby (M. agilis) and Southern Lowland Cuscus $(P$. intercastellanus) (Woxvold 2008:69; Coffey Natural Systems 2009:12-47) (Figure 10). More specifically, in 'winter they live upon yams, bananas, and fish. In August the hunting season commences, and for two or three months they live almost entirely on the flesh of the wallaby' (Turner 1878:481). However, what is the history of this hunting and did the early ancestors of these coastal people similarly supplement diets with hunted animals or were they marine subsistence specialists? In this connection, Allen (1977a:450) posits that coastal locations with little access to terrestrial resources may have been too 'restrictive' for early maritime colonisers and their 'more general economy'. While the Loloata Island site is obviously located on the coast, unfortunately at this site subsistence evidence is too scant to shed detailed light on this question.

The faunal assemblage at Edubu 1 concurs in part with Allen's (1977a) hypothesis that early peoples of the Port Moresby region practised a mixed marine-terrestrial subsistence economy. While it is now clear that maritime (Lapita) peoples moved into the Port Moresby 


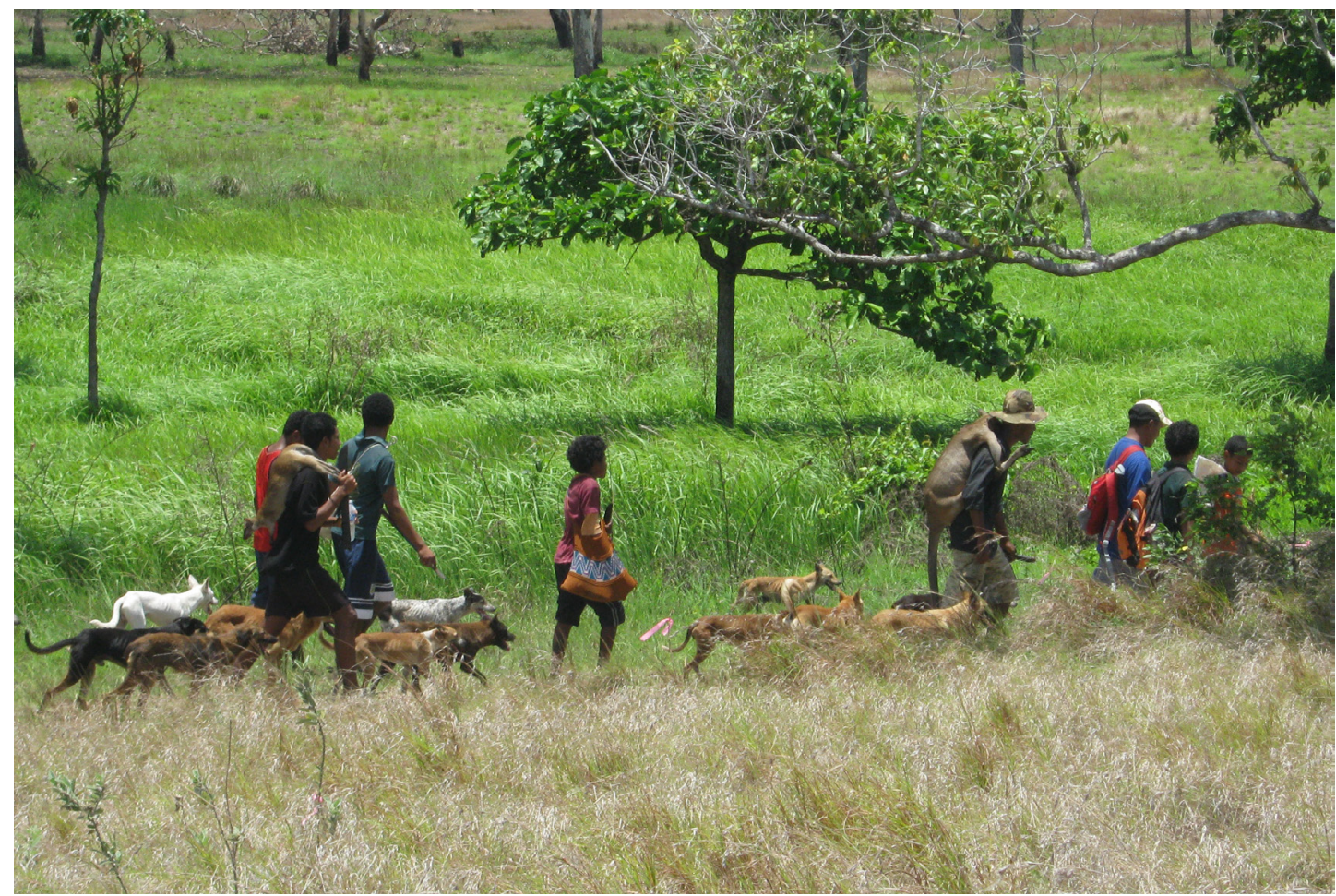

Figure 10. Hunting party with three wallabies and hunting dogs returning to Boera village via north side of Moiapu creek, 17 October 2009. The wallabies were hunted a few kilometres inland of Edubu 1. Photo: Ian J. McNiven.

coast well before 2000 years ago, the view that these maritime colonists exploited a wide range of marine and terrestrial foods has been reinforced. In common with Nebira 4, the faunal assemblage at Edubu 1 included terrestrial hunting focusing on macropods with contributions by pig, snake and freshwater turtle, while the marine faunal suite included fish, sea urchins, turtle and an extensive array of shellfish. In this sense, terminal Lapita occupants of Edubu 1 practised a more mixed economy than the more marine specialised Lapita-period subsistence practices seen on nearby shoreline sites at Caution Bay, such as Bogi 1 (McNiven et al. 2011). While the more mixed terrestrial-marine subsistence regime at Edubu 1 can be attributed in large part to the site's location $1 \mathrm{~km}$ inland from the shoreline, the question of why these terminal-Lapita-period peoples chose to establish a site inland away from the coast remains to be determined. For example, was Edubu 1 part of the seasonal round of the same peoples who occupied shoreline sites such as Bogi 1, or was it used by more terrestrially oriented inland peoples who were in close interaction with coastal peoples, as was the case of inland-coastal relations during the early European contact period of the late 1800s-early 1900s? Whatever the case, it is clear that in the Caution Bay region a complex and diverse subsistence pattern existed for terminal-Lapita pottery-using peoples, whereby the ratio of terrestrial to marine foods in diets varied depending on context and site location. In this sense, Caution Bay Lapita sites have considerable potential to inform current debates on the degree of marine-protein specialisation by Lapita peoples of the Western Pacific and factors influencing the incorporation of wild and domesticated terrestrial animal foods (Field et al. 2009; Valentin et al. 2010). At this juncture, whether cultivated plant foods contributed significantly to Lapita diets at Caution Bay remains hypothetical, but it is plausible that plant food was cultivated given the likelihood of Lapita agriculture across the Western Pacific (Kirch 1997; Spriggs 1997; Kennett et al. 2006; Horrocks and Nunn 2007; Fall 2010; see also Fairbairn 2005:495) and major erosion and sedimentation at Edubu 1 (see below). The presence of pig in Edubu 1 suggests strongly that pigs were introduced to the region by at least 2500 years ago. 


\section{Firing and grassland formation}

Directly related to the issue of the history of macropod hunting is the history of the development of savannah and grasslands - the major habitat of macropods such as Agile Wallabies. Early European visitors to the Port Moresby region in the late 19th century commented on savannah vegetation and burning of grasslands to aid hunting of wallabies and most likely pigs (Turner 1878:471, 487; Romilly 1889:164; Seligmann 1910:87) (Figure 11). In the Caution Bay region, such landscape burning to aid wallaby hunting continues today (Woxvold 2008:67-68; pers. obs. 2009-2010). Eden (1974) argues that the distribution of Port Moresby savannah and grassland vegetation cannot be accounted for simply by environmental factors and that these vegetation zones are also the product of human burning associated with shifting cultivation and hunting. In terms of the former, the potential for widespread impact is considerable, given that 'the life of individual fields' is usually only three to four years, and the principal local crops of banana (Musa sp.), taro (Colocasia sp.), sweet potato (Ipomoea batatas) and yam (Dioscorea sp.) involve considerable ground disturbance (Eden 1974:106). Oram (1977:83) suggested that the savannah and grasslands along the coast between Boera and Lea Lea (i.e. Caution Bay area) were 'probably as a result of human occupation'.

Historisicing the long-term process of local anthropogenic grassland formation, Bulmer (1975:66) hypothesised that the early maritime colonisers of the Port Moresby region 'may have helped to clear some of the lowland forest in the course of gardening and hunting on the river plains'. Swadling (1977:38) added that because of poor soils and low rainfall, the Port Moresby region was 'probably not considered a good place to live' prior to the introduction of horticulture and the associated clearance of forest, which subsequently created grasslands that supported rich stocks of wallabies. While both Bulmer and Swadling place the start of anthropogenic grassland formation back 2000 years, Bulmer (1975:21) hypothesises that these grasslands 'were widespread by 1,000 years ago', given archaeological evidence for local settlement patterns and extensive wallaby hunting within the past 800 years at sites such as Motupore (see Allen 1977a). Eden (1974:109) made the interesting point that while little evidence exists for the history and antiquity of anthropogenic deforestation and grassland formation in the Port Moresby region, 'it cannot be questioned that, even at rates of clearance significantly below those of today, the present savanna and grassland could readily have been created by cultivating peoples since about 2000 BP. The savanna and grassland may therefore represent the cumulative impact of cultivation and burning during such a period.'

The presence of macropod remains in Edubu 1 indicates that the necessary savannah and grassland habitats for wallabies were present in the Caution Bay area by at least 2600 years ago. Thus, it is possible that these savannah and grassland habitats were maintained, at least in part, by anthropogenic firing regimes similar to those recorded historically, and were initiated during the Lapita settlement of the coast sometime between 2900 and 2500 years ago when inland peoples became more attracted to this coastline for its new trade and other opportunities for social interaction generated by the newly established Lapita settlements at Bogi 1 and other nearby locations. Alternatively, landscape firing at Caution Bay may have a much longer antiquity: coring of Kosipe Swamp located $70 \mathrm{~km}$ inland indicates that people have been firing the landscape in the broader Port Moresby region for at least 40,000 years (Hope 2009). Furthermore, Hope et al. (1983:41) suggest that maintenance of grasslands and savannah in the Markham Valley on the northeast coast of Papua New Guinea by anthropogenic burning over the past 9000 years (Garrett-Jones 1979) opens the possibility of similar long-term firing in the Port Moresby region. Bulmer (1971:39) rightly points out that 'pollen samples need to be obtained in order to learn how long ago the forest was cleared and what other ecological 


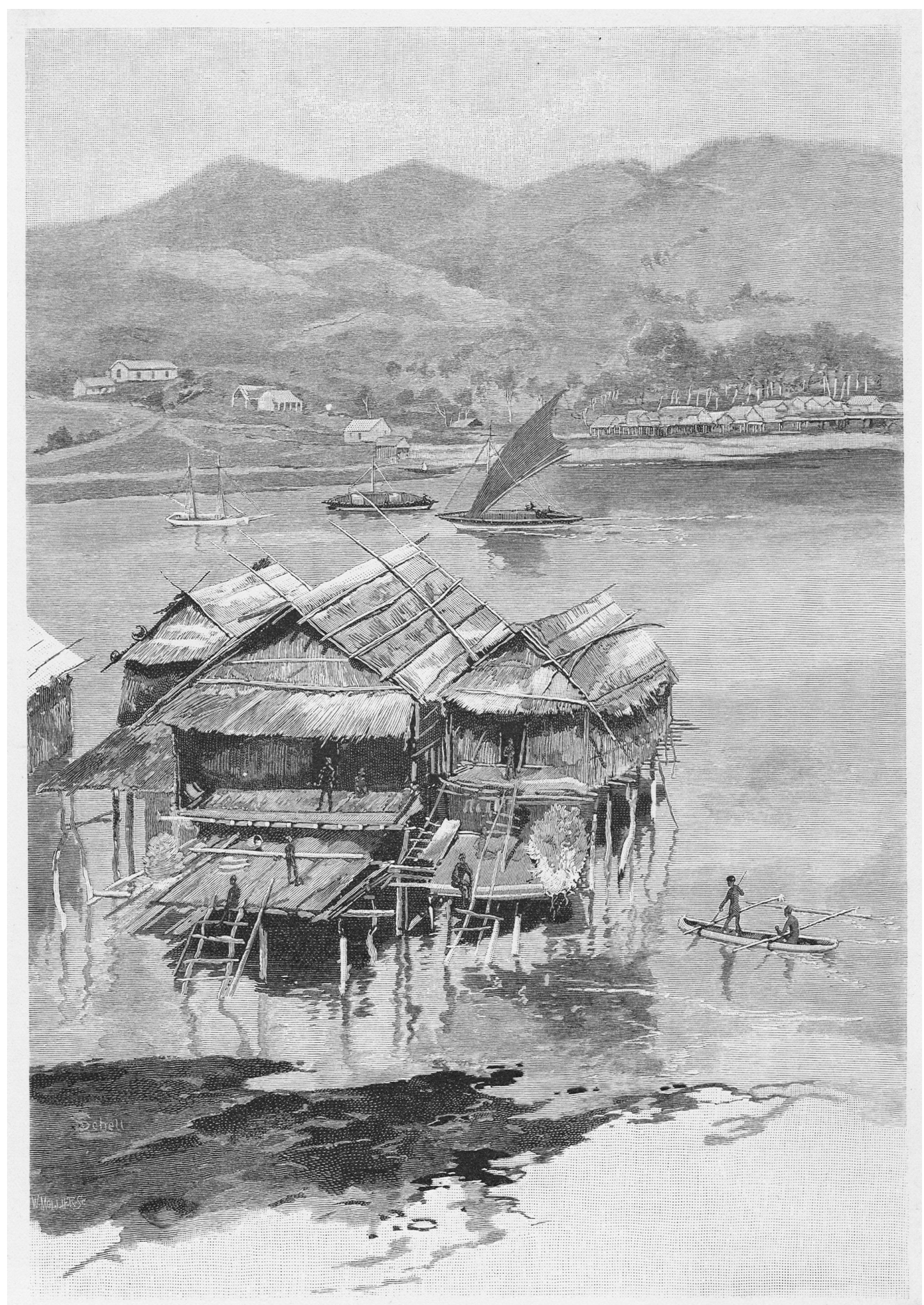

Figure 11. Late 19th century view of Port Moresby, showing grassy hills which reflect the long-term impact of human landscape burning (from Lawes 1886:663).

clues can be established concerning that period'. In this connection, pollen cores taken from mangroves fringing Caution Bay by Rowe and McNiven in 2010 will hopefully shed light on this question. 


\section{Erosion and coastal progradation}

Bulmer (1971:41) hypothesised that 'clearance of the lowland forest would have accelerated the deposition of sediments on the river plains, and consequently the extension of the swamplands surrounding the river mouth'. In particular, she points to likely coastal progradation of $4.8 \mathrm{~km}$ at Galley Reach (including the mouth of the Laloki River) in the northern part of the study region (Bulmer 1978:13, 14, 73). While the rate of slope erosion and lowland deposition in the Port Moresby region is likely to be lower than many other regions of New Guinea due to low local rainfall (Mabbutt et al. 1965:110; Bleeker 1983:177), Bulmer rightly identifies an anthropogenic dimension to landscape evolution and shoreline progradation, with major potential consequences for long-term human settlement of the region.

Löffler (1977:8-9) notes that landscape burning 'makes the ground highly susceptible to both rain splash erosion and unconcentrated wash' and that 'rain splash erosion appears to be severe where frequent burning is practised and where it is responsible for the removal of large quantities of soil'. Indeed, 'slope wash has ... been responsible for a near complete removal of the soil cover on most of the slopes in the Port Moresby area, irrespective of rock type' (Löffler 1977:8; see also Spenceley and Alley 1986). In the Caution Bay study area, exposure of uplifted fossiliferous limestone deposits of probable Pleistocene age (Mabbutt et al. 1965:14, 30, 107) is also consistent with considerable erosion and stripping of overlying surface sediments (see also Löffler 1977:6).

Edubu 1 was formed by rapid accumulation of $90 \mathrm{~cm}$ of sediment mostly over a period of up to 300 years between approximately $2350 \mathrm{cal} \mathrm{BP}$ and $2650 \mathrm{cal} \mathrm{BP}$. These sediments (SUs 1-3) were sitting on culturally sterile sediments (SU4) exhibiting a dramatically different layer orientation. While it is possible that SU4 sediments originally represented horizontal layers that have since been tilted through tectonic warping, it is more probable that the steep layer orientation reflects sediment accumulation on a steeper palaeo slope. This hypothesis is consistent with the nearby slope flanking the gully on the northern parts of the site. Whatever the case, the dramatic stratigraphic change between SU4 and SU3 represents a disconformity in soft sediments associated with an equally dramatic change in depositional context at Edubu 1. The surface of SU4 appears to be an erosion surface as its associated stratigraphy has not been homogenised and obliterated by soil formation and turbation processes. While detailed sediment analyses have yet to be undertaken, preliminary stratigraphic assessment from excavations across the Caution Bay coast to hinterland suggests that cultural deposition at Edubu 1 commenced soon after a period of erosion in the local landscape.

The most likely source for accumulating sediments forming SUs 1 to 3 is slightly more elevated land inland of Edubu 1. That is, eroded sediments from further inland moved downslope towards the coast and accumulated at Edubu 1. This sediment accumulation buried cultural materials left at the site by its occupants to create the archaeological deposit we see today. A direct correspondence between rapid sedimentation and cultural materials suggests strongly that upslope erosion and concomitant downslope sedimentation were associated with human landscape disturbance. Indeed, rapid sedimentation at Edubu 1 ceased once cultural materials stopped being discarded at the site perhaps 2000 years ago. We hypothesise that a key source of this landscape disturbance was firing of the local vegetation to maintain savannah and grassland habitats for macropods, particularly wallaby-hunting practices. It is also possible that ground disturbance was associated with gardening practices which accelerated downslope sedimentation (see Gosden and Pavlides 1994:169; Gosden and Webb 1994; Spriggs 1997:8586, 88, 2010; Kennett et al. 2006:278). To what extent possible increased gardening activities reflected the introduction of agriculture or intensification of existing agricultural practices with the arrival of Lapita peoples is unknown. Previous hypotheses have linked the introduction of agriculture along the south coast with the arrival of pottery-using peoples 2000 years ago 
(e.g. Harris 1995:853) or ca. 2600 years ago (McNiven et al. 2006:74). Clearly, continued research into the history of agriculture in the region, including Torres Strait, will be critical to understanding associated landscape transformations, and requires further development of multi-proxy approaches integrating archaeological (e.g. Barham and Harris 1985; Parr and Carter 2003), geomorphological (e.g. Barham 1999) and palynological indicators (e.g. Rowe 2007; McNiven et al. 2010) (see also Fairbairn 2005).

Broader support for hypothesised increased landscape modification and sedimentation regimes linked to changing land-use practices comes from analysis of sediments at Waigani Lake east of Caution Bay and immediately north of Port Moresby (Figure 1). A dramatic increase in the deposition of fluvial clay sediments in the lake between $2540 \pm 80 \mathrm{BP}$ (ca. 2600 cal BP) and ca. 1200 years ago reflects increased input of flood waters and sediments from the nearby Laloki River, linked to increased effective precipitation (Osborne et al. 1993:607608). However, Osborne et al. (1993:608) also suggest that increased sedimentation may be 'due to an increase in run-off generated by changing land-use or vegetation cover within the catchment area'. The fact that ca. 2600-2650 cal BP marks the establishment of Edubu 1 and a major increase in sedimentation provides increased support for the influence of humans on sedimentation regimes at Waigani Lake.

The consequences of landscape burning and slope erosion throughout the past 25003000 years in the Port Moresby region are likely to have had cumulative impacts on land-use practices, particularly in relation to responses to repositioning of shorelines associated with coastal progradation and sea level change. For example, Summerhayes and Allen (2007:103) hypothesise that Nebira 4 may have been much closer to the sea in the past. Further to the west in the eastern Gulf of Papua, Swadling et al. (1976:56) similarly discuss the potential impact of major coastal progradation over a distance of $20-25 \mathrm{~km}$ during the past 6000 years on settlement patterns and land-use strategies. In the Caution Bay region, Pain and Swadling (1980) document a series of palaeo shorelines in the form of 'sandspits' separated by mangrove forests across the lower reaches of the Vaihua River. While they associate shoreline development with lowering sea levels in the past 6000 years, it is also likely that deposition of terrestrial sediments in the intertidal zone from inland erosion associated with human land-use activities contributed to shoreline changes and mangrove development. While coastal progradation may have increased the distance of sites such as Edubu 1 to the coast by only a few hundred metres, the impact of mangrove development and changing marine resource availability on local subsistence practices may have been considerable. Analysis of sediment cores taken across mangrove forests at Caution Bay by two of us (CR and IM) will shed further light on the history of local shoreline development and how people contributed and responded to such changes.

\section{Conclusion}

The results of recent excavations at Caution Bay will transform understandings of Port Moresby region archaeology and understandings of the human history of southern coastal Papua New Guinea. Critically in terms of this chapter, the extended chronology for human settlement of the region provides considerable scope to understand changes in landscape engagements and transformations associated with the arrival of Lapita colonists 2900 years ago. Whereas elsewhere in Remote Oceania, Lapita colonists represent the first human presence in landscapes, in the Port Moresby region, like much of Near Oceania, Lapita colonists arrived and engaged with places already transformed by more than 1000 years of prior human settlement. In this sense, the establishment of long-term Lapita settlements in the Port Moresby region was a more complex, negotiated process compared with Remote 
Oceania, as it involved interactions with existing social and environmental landscapes. While the nature of this process of negotiation remains to be more fully explored - a process towards which we make initial steps in this paper - it is clear that the result was a complex mosaic of local and immigrant peoples with different cultural values, processes of environmental and social interaction, and histories. While sharing the same geographical setting, the ways local and immigrant groups chose to engage, transform and define this setting will reflect these differences. As Gosden and Webb (1994:48) cogently note, 'Land use is culturally determined, arising from choices people make about how to provision the social system.' To what extent such differences were maintained, hybridised and transformed over succeeding generations and centuries is the focus of ongoing research. Clearly, understanding how such differences were manifested in different land and sea engagements and environmental transformations will require the combined expertise of archaeological and palaeoenvironmental investigators. The co-determining and mutually constitutive nature of human-environmental relationships will be evident in archaeological sites as much as it will be registered in pollen cores, a theoretical point we have come to appreciate better through the work of Peter Kershaw.

\section{Acknowledgements}

For assistance with shell analyses we thank Helene Tomkins, Janet Sypkens and Shoshana Grounds. Helpful comments on an earlier draft of this chapter were kindly provided by anonymous referees. Thanks to Cathy Carigiet for Figure 7 and drawing the sherds for Figure 6, and Kara Rasmanis and Toby Wood for kindly preparing the figures.

\section{References}

Allen, J. 1972. Nebira 4: an early Austronesian site in central Papua. Archaeology and Physical Anthropology in Oceania 7(2):92-124.

Allen, J. 1977a. Fishing for wallabies: trade as a mechanism for social interaction, integration and elaboration on the central Papuan coast. In: Friedman, J. and Rowlands, M.J. (eds), The Evolution of Social Systems, pp. 419-455. London: Duckworth.

Allen, J. 1977b. Management of resources in prehistoric coastal Papua. In: Winslow, J.H. (ed), The Melanesian Environment, pp. 35-44. Canberra: ANU Press.

Allen, J. 1991. Hunting for wallabies: the importance of Macropus agilis as a traditional food resource in the Port Moresby hinterland. In: Pawley, A. (ed), Man and a Half: Essays in Pacific Anthropology and Ethnobiology in Honour of Ralf Bulmer, pp. 457-451. The Polynesian Society Memoir 48. Auckland: The Polynesian Society.

Barham, A.J. 1999. The local environmental impact of prehistoric populations on Saibai Island, northern Torres Strait, Australia: enigmatic evidence from Holocene swamp lithostratigraphic records. Quaternary International 59:71-105.

Barham, A.J. and Harris, D.R. 1985. Relict field systems in the Torres Strait region. In: Farrington, I.S. (ed), Prehistoric Intensive Agriculture in the Tropics, pp. 247-283. BAR International Series 232.

Bleeker, P. 1983. Soils of Papua Nerw Guinea. Canberra: ANU Press.

Bulmer, S. 1971. Prehistoric settlement patterns and pottery in the Port Moresby area. Journal of the Papua New Guinea Society 5:28-91.

Bulmer, S. 1975. Settlement and economy in prehistoric Papua New Guinea: a review of the archaeological evidence. Journal de la Société des Océanistes 31:7-75.

Bulmer, S. 1978. Prehistoric culture change in the Port Moresby region. Unpublished PhD thesis, University of Papua New Guinea. 
Bulmer, S. 1979. Prehistoric ecology and economy in the Port Moresby region. New Zealand Journal of Archaeology 1:5-27.

Chalmers, J. 1887. Pioneering in New Guinea. London: Religious Tract Society.

Coffey Natural Systems 2009. PNG LNG Project: Environmental Impact Statement. Prepared by Coffey Natural Systems Pty Ltd, 126 Trenerry Crescent, Abbotsford Victoria 3067. Australia.

David, B., Fairbairn, A., Aplin, K., Murepe, L., Green, M., Stanisic, J., Weisler, M., Simala, D., Kokents, T., Dop, J. and Muke, J. 2007. OJP, a terminal Pleistocene archaeological site from the Gulf Province lowlands, Papua New Guinea. Archaeology in Oceania 42:31-33.

David, B., Araho, N., Barker, B., Kuaso, A. and Moffat I. 2009. Keveoki 1: exploring the hiri ceramics trade at a short-lived village site near the Vailala River, Papua New Guinea. Australian Archaeology 68:11-23.

David, B., McNiven, I.J., Richards, T., Connaughton, S., Leavesley, M., Barker, B. and Rowe, C. In press. Lapita sites in the Central Province of mainland Papua New Guinea. World Archaeology.

Davies, H.L. and Smith, I.E. 1971. Geology of eastern Papua. Geological Society of America Bulletin 82:3299-3312.

Eden,M.J.1974. The origin and status of savannah and grassland in southern Papua. Transactions of the Institute of British Geographers 63:97-110.

Enright, N.J. and Gosden, C. 1992. Unstable archipelagos: south-west Pacific environment and prehistory since 30,000 B.P. In: Dodson, J. (ed), The Naïve Lands: Prehistory and Environmental Change in Australia and the South-West Pacific, pp. 160-198. Melbourne: Longman Cheshire.

Fairbairn, A. 2005. An archaeobotanical perspective on Holocene plant-use practices in lowland northern New Guinea. World Archaeology 37(4):487-502.

Fairbairn, A., Hope, G. and Summerhayes, G. 2006. Pleistocene occupation of New Guinea's highland and subalpine environments. World Archaeology 38:371-386.

Fall, P.L.2010. Pollen evidence for plant introductions in a Polynesian tropical island ecosystem, Kingdom of Tonga. In: Haberle, S., Stevenson, J. and Prebble, M. (eds), Altered Ecologies: Fire, Climate and Human Influence on Terrestrial Landscapes, pp. 253-271. Terra Australis 32. Canberra: ANU E Press.

Felgate, M. 2001. A Rovania ceramic sequence and the prehistory of Near Oceania: work in progress. In: Clark, G.R., Anderson, A.J. and Vunidilo, T. (eds), The Archaeology of Lapita Dispersal in Oceania: Papers from the Fourth Lapita Conference, June 2000, Canberra, Australia, pp. 39-60. Terra Australis 17, Pandanus Books, Canberra.

Field, J.S., Cochrane, E.E. and Greene, D.M. 2009. Dietary change in Fijian prehistory: isotopic analyses of human and animal skeletal material. Journal of Archaeological Science 36:1547-1556.

Garrett-Jones, S.E. 1979. Evidence for changes in Holocene vegetation and lake sedimentation in the Markham Valley, Papua New Guinea. Unpublished PhD thesis, Australian National University, Canberra.

Glaessner, M.F. 1952. Geology of Port Moresby, Papua. In: Glaessner, M.F. and Rudd, E.A. (eds), Sir Douglas Mawson Anniversary Volume: Contributions to Geology in Honour of Professor Sir Douglas Mawson's 70th Birthday Anniversary Presented by Colleagues, Friends and Pupils, pp. 63-86. Adelaide: The University of Adelaide.

Gosden, C. and Pavlides, C. 1994. Are islands insular? Landscape vs. seascape in the case of the Arawe Islands, Papua New Guinea. Archaeology in Oceania 29:162-171.

Gosden, C. and Webb, J. 1994. The creation of a Papua New Guinean landscape: archaeological and geomorphological evidence. Journal of Field Archaeology 21:29-51. 
Haberle, S.G. 1998. Late Quaternary vegetation change in the Tari Basin, Papua New Guinea. Palaeogeography, Palaeoclimatology, Palaeoecology 137:1-24.

Haberle, S., Hope, G.S. and van der Kaars, S. 2001. Biomass burning in Indonesia and Papua New Guinea: natural and human induced fire events in the fossil record. Palaeogeography, Palaeoclimatology, Palaeoecology 171:259-268.

Harris, D.R. 1995. Early agriculture in New Guinea and the Torres Strait divide. Antiquity 69:848-854.

Hiscock, P. 2008. Archaeology of Ancient Australia. London and New York: Routledge.

Hope, G.S. 1976. The vegetational history of Mt. Wilhelm, Papua New Guinea. Journal of Ecology 64(2):627-663.

Hope, G.S. 1983. The vegetational changes of the last 20,000 years at Telefomin, Papua New Guinea. Journal of Tropical Geography 4(1):25-33.

Hope, G.S. 2009. Environmental change and fire in the Owen Stanley Ranges, Papua New Guinea. Quaternary Science Reviews 28:2261-2276.

Hope, G.S. and Haberle, S.G. 2005. The history of the human landscapes of New Guinea. In: Pawley, A., Attenborough, R., Golson, J. and Hide, R. (eds), Papuan Pasts: Cultural, Linguistic and Biological Histories of Papuan-Speaking Peoples, pp.541-554.Pacific Linguistics 572. Canberra: Research School of Pacific and Asian Studies, The Australian National University.

Hope, G.S., Golson, J. and Allen, J. 1983. Palaeoecology and prehistory in New Guinea. Journal of Human Ecology 12(1):37-60.

Horrocks, M. and Nunn, P.D. 2007. Evidence for introduced taro (Colocasia esculenta) and lesser yam (Dioscorea esculenta) in Lapita-era (c.3050-2500 cal. yr BP) deposits from Bourewa, southwest Viti Levu Island, Fiji. Journal of Archaeological Science 34(5):739-748.

Irwin, G. and Holdaway, S. 1996. Colonisation, trade and exchange: from Papua to Lapita. In: Davidson, J., Irwin, G., Leach, B., Pawley, A. and Brown, D. (eds), Oceanic Culture History: Essays in Honour of Roger Green, pp. 225-235. Dunedin: New Zealand Archaeological Society.

Jones, R. 1969. Fire-stick farming. Australian Natural History 16:224-228.

Kennett, D., Anderson, A. and Winterhalder, B. 2006. The ideal free distribution, food production, and the colonization of Oceania. In: Kennett, D. and Winterhalder, B. (eds), Behavioral Ecology and the Transition to Agriculture, pp. 265-288. Berkeley: University of California Press.

Kershaw, A.P. 1974. A long continuous pollen sequence from north-eastern Australia. Nature 251:222-223.

Kershaw, A.P. 1993. Palynology, biostratigraphy and human impact. The Artefact 16:12-18.

Kirch, P.V. 1997. The Lapita Peoples: Ancestors of the Oceanic World. Oxford: Blackwell.

Lawes, W.G. 1879. Ethnological notes on the Motu, Koitapu and Koiari tribes of New Guinea. The Journal of the Anthropological Institute of Great Britain and Ireland 8:369-377.

Lawes, W.G. 1886. Insular Australasia: New Guinea. In: Garran, A. (ed), Picturesque Atlas of Australasia, Vol. III, pp. 661-668. Sydney: Picturesque Atlas Pub. Co.

Lilley, I. 2008. Flights of fancy: fractal geometry, the Lapita dispersal and punctuated colonisation in the Pacific. In: Clark, G., Leach, F. and O'Connor, S. (eds), Islands of Inquiry: Colonisation, Seafaring and the Archaeology of Maritime Landscapes, pp. 75-86. Terra Australis 29. Canberra: ANU E Press.

Löffler, E. 1977. The impact of traditional man on landforms in Papua New Guinea. In: Winslow, J.H. (ed), The Melanesian Environment, pp. 3-10. Canberra: ANU Press.

Mabbutt, J.A., Heyligers, P.C., Scott, R.M., Speight, J.G., Fitzpatrick, E.A., McAlpine, J.R. and Pullen, R. 1965. Lands of the Port Moresby-Kairuku Area, Territory of Papua and New Guinea. Land Research Series No. 14. Melbourne: CSIRO. 
McAlpine,J.R., Keig, G. and Falls, R. 1983. Climate of Papua Nerw Guinea. Canberra: Australian National University Press.

McNiven, I.J., Dickinson, W.R., David, B., Weisler, M., von Gnielinski, F., Carter, M. and Zoppi, U. 2006. Mask Cave: red-slipped pottery and the Australian-Papuan settlement of Zenadh Kes (Torres Strait). Archaeology in Oceania 41(2):49-81.

McNiven, I.J., David, B., Aplin, K., Pivoru, M., Pivoru, W., Sexton, A., Brown, J., Clarkson, C., Connell, K., Stanisic, J., Weisler, M., Haberle, S., Fairbairn, A. and Kemp, N. 2010. Historicising the present: late Holocene emergence of a rainforest hunting camp, Gulf Province, Papua New Guinea. Australian Archaeology 71:41-56.

McNiven, I.J., David, B., Richards, T., Aplin, K., Asmussen, B., Mialanes, J., Leavesley, M., Faulkner, P. and Ulm, S. 2011. New direction in human colonisation of the Pacific: Lapita settlement of south coast New Guinea. Australian Archaeology 72:1-6.

Mooney, S.D., Harrison, S.P., Bartlein, P.J., Daniau, A.-L., Stevenson, J., Brownlie, K.C., Buckman, S., Cupper, M., Luly, J., Black, M., Colhoun, E., D'Costa, D., Dodson, J., Haberle, S., Hope, G.S., Kershaw, P, Kenyon, C., McKenzie, M. and Williams, N. 2011. Late Quaternary fire regimes of Australasia. Quaternary Science Reviews 30:28-46.

O'Connell, J. and Allen, J. 2004. Dating the colonization of Sahul (Pleistocene Australia-New Guinea): a review of recent research. Journal of Archaeological Science 31:835-853.

Oram, N. 1977. Environment, migration and site selection in the Port Moresby coastal area. In: Winslow, J.H. (ed), The Melanesian Environment, pp. 74-99. Canberra: ANU Press.

Osborne, P.L., Humphreys, G.S. and Polunin, N.V.C. 1993. Sediment deposition and late Holocene environmental change in a tropical lowland basin: Waigani Lake, Papua New Guinea. Journal of Biogeography 20:599-613.

Paijmans, K. 1975. Explanatory Notes to the Vegetation Map of Papua New Guinea. Land Research Series No. 35. Melbourne: CSIRO.

Pain, C. and Swadling, P. 1980. Sea level changes, coastal landforms and human occupation near Port Moresby. Science in New Guinea 7:57-68.

Parr, J.F. and Carter, M. 2003. Phytolith and starch analysis of sediment samples from two archaeological sites on Dauar Island, Torres Strait, northeastern Australia. Vegetation History and Archaeobotany 12:131-141.

Pieters, P.E. 1978. Port Moresby, Kalo, Aroa: Papua New Guinea. Sheets SC/55-6, -7 and -11. Explanatory Notes and 1:250,000 Geological Map. Dept. of National Development, Bureau of Mineral Resources, Geology and Geophysics. Dept. of Minerals and Energy, Papua New Guinea, Geological Survey of Papua New Guinea. Canberra: Australian Government Publishing Service.

Reimer, P.J., Baillie, M.G.L., Bard, E., Bayliss, A., Beck, J.W., Blackwell, P.G., Bronk Ramsey, C., Buck, C.E., Burr, G.S., Edwards, R.L., Friedrich, M., Grootes, P.M., Guilderson, T.P., Hajdas, I., Heaton, T.J., Hogg, A.G., Hughen, K.A., Kaiser, K.F., Kromer, B., McCormac, F.G., Manning, S.W., Reimer, R.W., Richards, D.A., Southon, J.R., Talamo, S., Turney, C.S.M., van der Plicht, J. and Weyhenmeyer, C.E. 2009. IntCal09 and Marine09 radiocarbon age calibration curves, 0-50,000 years cal BP. Radiocarbon 51(4):1111-1150.

Romilly, H. 1889. From My Verandah in New Guinea: Sketches and Traditions. London: David Nutt.

Rowe, C. 2007. A palynological investigation of Holocene vegetation change in Torres Strait, seasonal tropics of northern Australia. Palaeogeography, Palaeoclimatology, Palaeoecology 251:83-103.

Seligmann, C.G. 1910. The Melanesians of British New Guinea. Cambridge: Cambridge University Press.

Singh, G., Kershaw, A.P. and Clark, R. 1981. Quaternary vegetation and fire history in Australia. 
In: Gill, A.M., Groves, R.A. and Noble, I.R. (eds), Fire and the Australian Biota, pp. 23-54. Canberra: Australian Academy of Science.

Smith, I.E. and Milsom, J.S. 1984. Late Cenozoic volcanism and extension in Eastern Papua. Geological Society, London, Special Publications 16:163-171.

Specht, J. and Torrence, R. 2007. Lapita all over: land use on the Willaumez Peninsula, Papua New Guinea. In: Bedford, S., Sand, C. and Connaughton, S. (eds), Oceanic Explorations: Lapita and Western Pacific Settlement, pp.71-96. Terra Australis 26. Canberra: ANU E Press. Spenceley, A.P. and Alley, N.F. 1986. Effect of human settlement on soil erosion in the Owen Stanley Range, Papua New Guinea. Search 17:213-216.

Spriggs, M. 1997. The Island Melanesians. Oxford: Blackwell.

Spriggs, M. 2010. Geomorphic and archaeological consequences of human arrival and agricultural expansion on Pacific islands: A reconsideration after 30 years of debate In: Haberle, S., Stevenson, J. and Prebble, M. (eds), Altered Ecologies: Fire, Climate and Human Influence on Terrestrial Landscapes, pp. 239-252. Terra Australis 32. Canberra: ANU E Press.

Stone, O.C. 1876. Description of the country and natives of Port Moresby and neighbourhood, New Guinea. Journal of the Royal Geographical Society of London 46:34-62.

Stuiver, M. and Reimer, P.J. 1993. Extended 14C database and revised CALIB radiocarbon calibration program. Radiocarbon 35:215-230.

Sullivan, M.E. and Sassoon, M. 1987. Prehistoric occupation of Loloata Island, Papua New Guinea. Australian Archaeology 24:1-9.

Summerhayes, G. and Allen,J.2007. Lapita writ small? Revisiting the Austronesian colonisation of the Papuan south coast. In: Bedford, S., Sand, C. and Connaughton, S. (eds), Oceanic Explorations: Lapita and Western Pacific Settlement, pp. 97-122. Terra Australis 26. Canberra: ANU E Press.

Summerhayes, G.R., Leavesley, M. and Fairbairn, A. 2009. Impact of human colonisation on the landscape: a view from the Western Pacific. Pacific Science 63(4):725-745.

Summerhayes, G.R., Leavesley, M., Fairbairn, A., Mandui, H., Field, J., Ford, A. and Fullagar, R. 2010. Human adaptation and plant use in Highland New Guinea 49,000 to 44,000 years ago. Science 330:78-81.

Swadling, P.1977. A review of the traditional and archaeological evidence for early Motu, Koita and Koiari settlement along the central south Papuan coast. Oral History 5(2):37-57.

Swadling, P. and Hope, G.1992. Environmental change in New Guinea since human settlement. In: Dodson, J. (ed), The Naïve Lands: Prehistory and Environmental Change in Australia and the South-West Pacific, pp. 13-42. Melbourne: Longman Cheshire.

Swadling, P., Aitsi, L., Trompf, G. and Kari, M. 1976. Beyond the early oral traditions of the Austronesian speaking people of the Gulf and Western Central Provinces: a speculative appraisal of early settlement in the Kairuku District. Oral History V:50-80.

Turner, W.Y. 1878. The ethnology of the Motu. The Journal of the Antbropological Institute of Great Britain and Ireland 7:470-499.

Turney, C.S.M., Kershaw, A.P., Moss, P., Bird, M.I., Fifield, L.K., Cresswell, R.G., Santos, G.M., Di Tada, M.L., Hausladen, P.A. and Zhou, Y. 2001. Redating the onset of burning at Lynch's Crater (North Queensland): implications for human settlement in Australia. Journal of Quaternary Science 16(8):767-771.

Valentin, F., Buckley, H.R., Herrscher, E., Kinaston, R., Bedford, S., Spriggs, M., Hawkins, S. and Neal, K. 2010. Lapita subsistence strategies and food consumption patterns in the community of Teouma (Efate,Vanuatu). Journal of Archaeological Science 37(8):1820-1829.

Vanderwal, R.L. 1973. Prehistoric studies in central coastal Papua. Unpublished PhD thesis, Australian National University, Canberra.

Vasey, D.E. 1982. Subsistence potential of the pre-colonial Port Moresby area, with reference 
to the hiri trade. Archaeology in Oceania 17(3):132-142.

White, J.P. and O'Connell, J.F. 1982. A Prehistory of Australia, Nerw Guinea and Sabul. Sydney: Academic Press.

Woxvold, I.A. 2008. Assessment and Impact Analysis of Terrestrial Biodiversity at the LNG Facilities Site, Central Province, Papua New Guinea. Report to Coffey Natural Systems, Australia. 